\title{
Assessment the Ecological and Physiological Status of Seagrasses in Representative Habitats at Hurgada and Safaga Provinces, Red Sea Coast, Egypt
}

\author{
A.A. Khalafallah", Soad A. Sheteawi*,Y. A. Geneid ${ }^{* *}$, Basma S. Essa* \\ *Botay. Department, Faculty of women for Arts, Science and Education, \\ Ain Shams University and ${ }^{* *}$ National Institute of Oceanography and \\ Fisheries (NIOF), Attaqa, Suez, Egypt
}

\begin{abstract}
C EAGRASS communities represent spatially complex and biomass producing systems. Present study investigated shallow water seagrass communities from four sites; two sites located at Hurgada (Abu Shaar and NIOF) and two sites located at Safaga (General Beach and Aza'at). Five seagrasses were identified in the studied sites; Halophila stipulacea (Forssk.) Asch., Halodule uninervis (Forssk.) Boiss., Halophila ovals (R.Br.) Hook. f., Thalassodendron ciliatum (Forssk.) Hartog and Syringodium isoetifolium (Forssk.) Hartog. Distribution of the recorded species and sediment texture explained the relation between species and sediment type, where Th. ciliatum prefers conglomerate sediments from coarse sand, $H$. uninervis prefers fine sandy sediments while $H$. stipulacea and $H$. ovalis prefer disjointed coarse sandy sediments. The soils of fine particles have high organic matter content than those constructed from conglomerate or disjointed coarse sand. Abu Shaar and NIOF sites contain low concentration of calcium carbonate compared to General Beach and Aza'at sites. Shoot biomass and density of the four seagrasses were highly affected by seasonality; where, they were increased in summer season than in winter. Photosynthetic pigments of $H$. stipulacea and $H$. uninervis significantly increased in winter than in summer, while those of $H$. ovalis and Th. ciliatum showed the reverse. Total carbohydrates and crude protein of the four seagrasses in the four sites increased in winter than in summer. Soluble compounds (Total soluble sugars, total soluble amino acids and protein) significantly increased in the four species in summer season than in winter and increased in seagrasses growing in low depth than deepest locations. Nitrogen and phosphorus didn't show significant variation in seagrasses tissues in the two seasons or sites. $\mathrm{Na}^{+}, \mathrm{K}^{+}$, $\mathrm{Mg}^{++}$and $\mathrm{Ca}^{++}$cations significantly increased in the four studied seagrasses in summer than in winter and in seagrasses growing in shallow habitats than the deepest ones. The current study indicated that the most important factors affecting the distribution of seagrasses in the study area is the quality of the sediments, while climatic factors and water depth affecting on productivity and metabolic processes of seagrasses. Recording $H$. uninervis at NIOF site and Syringodium isoetifolium at General Beach site for the first time indicated that
\end{abstract}


changes have been occurred in these environments to become suitable for appearance of these species.

Keywords: Seagrasses, Distribution, Sediment, Biomass, Physiology, Hurgada, Red Sea.

Seagrasses is one of the richest and most significant important coastal habitats and ecologically they are important marine species from all trophic levels (Bologna et al., 2013). They are flowering plants belonging to class Monocotyledoneae, growing, flowering and seedling under water, evolving from terrestrial origin and re-entered the sea millions years ago (Duke et al., 2007 and Heck et al., 2008). According to Barbier et al. (2011), seagrsses can provide additional services where, the leaves act as a filter, clearing the water of suspended sediments, leaves, roots and rhizomes take up and cycle nutrients. The complex root structure of seagrass beds secures and stabilizes sediments that providing essential shoreline protection and reduction of coastal erosion from extreme storm events (Bjork et al., 2008). Seagrasses leaves form a threedimensional habitat creating shelter for many other marine species. The leaves serve as a surface for attachment to a wide variety of small encrusting algae and animals. These in turn provide an important food source for larger seagrassassociated animals. In addition, they are a nursery ground for juvenile and larval stages of many commercial, recreational and subsistence fish and shellfish (Heck et al., 2003).

From 60 species of seagrass inhabit coastal waters worldwide (den Hartog 1970), six species were identified along the Red Sea Coast by Geneid (1995). Halodule uninervis, Thalassodendron ciliatum and Syringodium isoetifolium are belonging to family Cymodoceaceae and Halophila stipulacea, Halophila ovalis and Thalassia hemprichii belonging to family Hydrocharitaceae.

The main factors influencing the primary production of seagrasses are water temperature, underwater irradiance, and nutrients concentrations and availability. In addition, tidal exposure, coupled with desiccation stress, can be a limiting factor for seagrass growth in the intertidal zone (Lee et al., 2007 and Kim, 2013). The changes in these factors can alter seagrasses distribution, growth, productivity and physiological aspects. Longstaff and Dennison (1999) concluded that increase or reduction of soluble organic solutes (soluble sugars, free amino acids and proline) in most plants represents a response to the environmental factors (high or low temperature, high or low light intensity, salinity and others). Where, Lee et al. (2007) found that temperature significantly affects the biochemical processes that are involved in photosynthesis and respiration.

Due to the shallow depth and relatively weak exchange with the open sea, these systems are particularly vulnerable to eutrophication, recognized as a major problem worldwide (Marques et al., 2003). In addition, global warming and sea-

Egypt. J. Bot., 56, No. 1 (2016) 
level rise will have important consequences for aquatic ecosystems (Lawrence and Soame,).

Synoptic studies to date have examined the distribution, status and trends of seagrass habitat, and have clearly indicated that seagrasses are declining globally (Waycott et al., 2009). A synthesis of 215 published studies showed that seagrass habitat disappeared worldwide at a rate of $110 \mathrm{~km}^{2}$ per year between 1980 and 2006 (Waycott et al., 2009). In addition, Human populations in coastal areas continue to increase and by $2025,75 \%$ of the global population is projected to live in coastal areas (Bulleri and Chapman, 2010). Growing coastal populations are frequently accompanied by growing development pressure in these areas, converting previous vegetated systems to impervious unvegetated areas by constructing buildings, paving roads, and armoring shorelines with riprap and bulkheads. However, the actual status of individual seagrass species themselves has received little attention.

Seagrasses have low attention from Egyptian botanists while, it is important to document seagrass species diversity and distribution and to identify areas requiring conservation measures before significant areas and species are lost. Determining the extent of seagrass areas and the ecosystem values of seagrasses is now possible on a local scale for use by coastal zone managers to aid planning and development decisions. Knowledge of Egyptian seagrass distributions is still too limited for broad scale protection and management. Such information is needed to minimize future impacts on seagrass habitats. Therefore, the current plan aims to study the ecological and physiological status of seagrasses beds in the shallow shores at Hurgada and Safaga harbor

\section{Material and Methods}

Sites of study. Seagrass beds were sampled in four localities; Abu Shaar and National Institute of Oceanography and Fisheries (NIOF) located at north of Hurghada and General Beach and Aza'at located at Safaga (Fig. 1). Data were collected in August 2007 and January 2008. The studied sites were divided into 17 stands according to the change in depth, sediment type and vegetation type. The geographical location of each site was recorded by using GPS model Trimbel Juno SD, and the depth were measured and tabulated in Table 1.

The study area characterized by hot and dry climate, where the annual mean of maximum and minimum temperature is 28.8 and $20.6^{\circ} \mathrm{C}$, relative humidity is 49.3 and the annual mean of rainfall is $0.4 \mathrm{~mm}$.

\section{Water and sediment analysis}

Water and sediment samples were collected from the studied 17 stands and were transferred to the laboratory in an ice box for analysis. Water samples were filtered by using filter paper (whatman No. 44) before analysis (English et al., 1997). The sediment samples were dried in air and used for analysis. 
$\mathrm{pH}$ of water samples was measured using a glass and calomel electrode by a Backman $\mathrm{pH}$ meter. Electrical conductivity was estimated using a conductivity meter according to (Allen, 1989). Anions $\left(\mathrm{CO}_{3}^{--}, \mathrm{HCO}_{3}^{-}, \mathrm{Cl}^{-}\right.$and $\left.\mathrm{SO}_{4}^{--}\right)$were estimated according to Jackson (1967). Values were expressed as meq/L. $\mathrm{Na}^{+}$ and $\mathrm{K}^{+}$were determined photometrically as described by Allen (1989). $\mathrm{Ca}^{++}$and $\mathrm{Mg}^{++}$were determined by EDTA titration method as described by Allen (1989). Salinity was determined by the argentometric method as described in American Public Health Association (1995). Total soluble salts (TSS) were determined by drying a known volume at $105^{\circ} \mathrm{C}$ for a constant weight. Sodium chloride was calculated by multiplying the values of chloride by 1.65 (American Public Health Association, 1995).
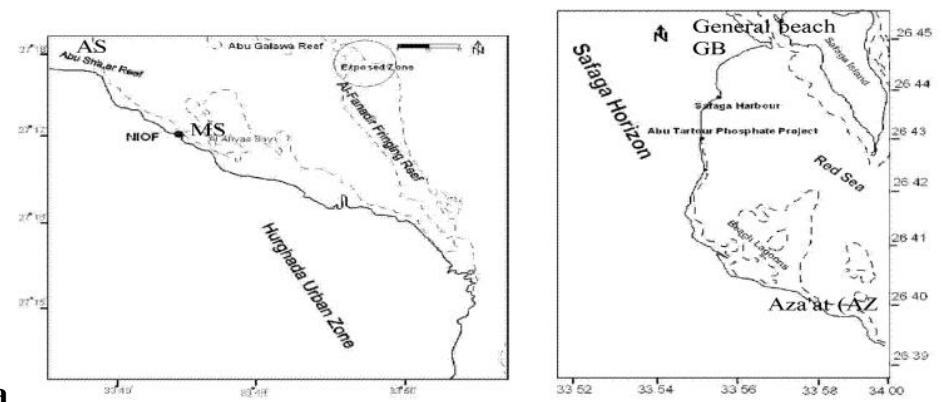

b
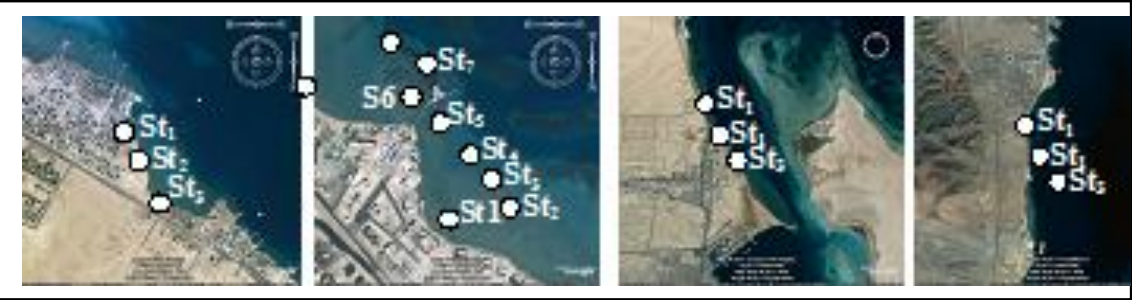

Abu Shaar

NIOF

General beach

Aza'at

Fig. 1. a- Map shows the four sites of the studied seagrass beds and b- distribution of 17 stands in the four sits.

TABLE 1. Geographical locations of the studied sites

\begin{tabular}{|l|l|l|l|l|l|}
\hline \multirow{2}{*}{ Harbor } & \multicolumn{2}{|l|}{ Site } & Long. & Lat. & $\begin{array}{l}\text { Mean Depth } \\
(\mathbf{m})\end{array}$ \\
\hline \multirow{2}{*}{ Hurgada } & I & Abu Shaar & $27^{\circ} 1734^{\prime \prime} 56$ & $33^{\circ} 4530^{\prime \prime} 90$ & $1.5 \pm 0.20$ \\
\cline { 2 - 6 } & II & Marine station & $27^{\circ} 17^{\prime} 00^{\prime \prime} 55$ & $33^{\circ} 46^{\prime} 22^{\prime \prime} 00$ & $1.2 \pm 0.80$ \\
\hline \multirow{2}{*}{ Safaga } & III & General beach & $26^{\circ} 4606^{\prime \prime} 78$ & $33^{\circ} 56^{\prime} 34^{\prime \prime} 08$ & $0.6 \pm 0.20$ \\
\cline { 2 - 6 } & IV & Aza'at & $26^{\circ} 41^{\prime} 03^{\prime \prime} 56$ & $33^{\circ} 56^{\prime} 00^{\prime \prime} 69$ & $2.5 \pm 0.50$ \\
\hline
\end{tabular}

Trace metals $(\mathrm{Cd}, \mathrm{Cu}, \mathrm{MN}, \mathrm{Zn}, \mathrm{B}, \mathrm{Al}$ and $\mathrm{Fe})$ were determined in water samples using the Inductively Coupled Plasma-Emission Spectrometry (ICP-ES) with Ultra Sonic Nebulizer (USN).

Egypt. J. Bot., 56, No. 1 (2016) 
Texture of the sediment samples were conducted by drying at $65^{\circ} \mathrm{C}$ for $96 \mathrm{hr}$. The samples were allowed to pass through a series of sieves (from 2 to $0.02 \mathrm{~mm}$ ) attached to automatic shaker to separate; gravel, coarse sand and fine sand. The pipette method of Carver (1971) was used for determination of clay and silt.

Calcium carbonate in the air-dried sediment was determined by the rapid titration method as described by Allen (1989). In addition, the organic carbon content was determined by the rapid titration method as described by Allen (1989). Organic matter was calculated by multiplying the values of organic carbon by 1.72 .

\section{Plant sampling and analysis}

Quadrate method as a non destructive method were used as described by English et al. (1997) to collect seagrasses samples during two seasons; Summer (August 2008) and Winter (January 2009) using snorkeling. The quadrate dimensions used were $0.5 \times 0.5 \mathrm{~m}\left(0.25 \mathrm{~cm}^{2}\right)$. The Seagrasses species were identified according to den Hartog (1970), Green and Short (2003), Boulos (2005), Short et al. (2006) and El Shaffai (2011). Seagrasses Samples were transferred in ice box to the laboratory for analysis. Vousher specimens were kept in the herbarium of Botany department, Women Faculty, Ain Shams University.

Determination of seagrass density

The numbers of seagrasses shoots or leaf pairs of the seagrass species were recorded. Seagrass density was calculated according to the following equation

Plant density $=$ No. of shoots or leaf pairs $/ m^{2}$

\section{Determination of biomass:}

The total living biomass of seagrasses was dried at $70^{\circ} \mathrm{C}$ for $72 \mathrm{hr}$ after removing epiphytes (Persga, 2004). After 72 hours, samples dry weights were determined.

\section{Determination of Photosynthetic pigments}

The leaf tissue was manually cleaned of any attached epiphytes and the nonphotosynthetic part of the leaf was removed. The photosynthetic pigments (chlorophyll $\mathrm{a}$, chlorophyll $\mathrm{b}$ and carotenoids) were extracted and determined in the fresh leaves according to the spectrophotometric method recommended by VonWettstein (1954) using the following equations:

Chlorophyll $a=9.78 \mathrm{X}(\mathrm{E})_{662}-0.99 \mathrm{X}(\mathrm{E})_{644}$

Chlorophyll $b=21.426 \mathrm{X}(\mathrm{E})_{644}-4.65 \mathrm{X}(\mathrm{E})_{662} \quad \mathrm{mg} / \mathrm{g}$ Fresh wt.

$\mathrm{mg} / \mathrm{g}$ Fresh wt.

Carotenoids $=4.695 \mathrm{X}(\mathrm{E})_{440.5}-0.286 \mathrm{X}(\mathrm{Chl} . \mathrm{a}+\mathrm{Chl} . \mathrm{b}) \mathrm{mg} / \mathrm{g}$ Fresh wt. 


\section{Estimation of carbohydrates}

The total soluble sugars were measured in an ethanolic extract of fresh seagrasses shoots, using phenol-sulfuric acid according to the method of Dubois et al. (1956). Total carbohydrates of seagrasses shoots were extracted by heating $0.2 \mathrm{~g}$ of plant powder in $2.5 \mathrm{ml}$ of $2 \mathrm{M} \mathrm{HCl}$ in sealed tubes at $100^{\circ} \mathrm{C}$ for a period of 2-5 hr (Chaplin and Kennedy, 1994). Carbohydrate content was estimated colorimetrically by the phenol sulfuric acid method as described by Dubios et al. (1956).

\section{Estimation of crude protein}

The crude protein was determined in the four seagrasses shoots using the micro-Kjeldhal method described by Allen (1989). The nitrogen content was multiplied by 6.25 to obtain the protein content (Association of Official Agricultural Chemists, 1975).

\section{Estimation of total soluble proteins}

The total soluble proteins in the four seagrases shoots were determined according to the method of Bradford (1976), serum albumin was used as standard.

\section{Estimation of total free amino acids}

The total free amino acids in the four seagrasses shoots were determined using ninhydrin reagent according to Moore and Stein (1954). Pure glycine was used as standard.

\section{Estimation of proline}

The proline content in fresh shoots of the four seagrasses was determined using the method of Bates et al. (1973). Pure proline was used as a standard.

\section{Estimation of nutrients content}

Total nitrogen ( $\mathrm{TN})$, phosphorus, potassium, sodium, calcium and magnesium concentrations were determined after digestion of powdered dry shoot material $(500 \mathrm{mg})$ in a digestion flask with $4 \mathrm{ml} \mathrm{H}_{2} \mathrm{SO}_{4}(98 \% \mathrm{v} / \mathrm{v})$. The digest was amended with $10 \mathrm{ml}$ of $\mathrm{H}_{2} \mathrm{O}_{2}(40 \% \mathrm{v} / \mathrm{v})$, brought to a final volume of $100 \mathrm{ml}$ with deionized water. Nitrogen was determined using the Kjeldahl method described by Allen (1989).

Phosphorus, potassium, sodium, calcium and magnesium were analyzed using ICP/OES (Spectro Ciros CCD).

\section{Statistical analysis}

Standard errors of the recorded data were calculated. Agglomerative clustering analysis technique according to Kruscal (1964) was applied to classify the studied stands based on water or sediment characteristics or floristic composition by using Community Analysis Package (CAP, 1999). Data of water and sediment were treated statistically using one way ANOVA and the means 
were compared by Duncan at $5 \%$. While, seagrass biomass, density and physiological parameters were statistically analyzed using two ways ANOVA as described by Snedecor and Cockran (1969). The means were compared by LSD at $5 \%$ using SPSS program version 16.

\section{Results}

Survey study and seagrasses distribution

Survey of the four localities (Abu-Shaar, NIOF, General Geach and Aza'at) was carried out through two successive seasons and the sites are described as follows.

\section{Abu Shaar site.}

Three seagrass species were recorded in small patches with approximately cover $75-80 \%$. The species are Thalassodendron Ciliatum (Forssk.) Hartog, Halophila stipulacea (Forssk.) Asch. and Halodule uninervis (Forssk.) Boiss. Th. Ciliatum species represented the dominant species as it was found in the three stands and found with the highest cover. H. stipulacea was found in stands 1 and 2, while $H$. uninervis was found in stand 2 and 3 with low cover.

\section{NIOF site.}

It is characterized by variable habitats that differ in their sediment structure and depth. Therefore, the eight studied stands show high difference in their floristic composition. The survey showed that the NIOF site contained 4 seagrass species distributed in the eight stands. Water depth of the $1^{\text {st }}$ and $2^{\text {nd }}$ stands is $0.60 \pm 0.05$ and their underlying sediment is conglomerate where seagrasses $T h$. ciliatum and $H$. stipulacea were recorded. In addition, the seagrass cover approximately $75-80 \%$ of the two stands area. Stands 3 and 4 have similar environmental characteristics with mean water depth $2.0 \pm 0.3 \mathrm{~m}$ and contain only one species (H. stipulacea) which covered about $85 \%$ of the total patch area. The $5^{\text {th }}$ and $6^{\text {th }}$ stands characterized by low water depth $(0.5 \pm 0.1 \mathrm{~m})$, sandy sediment and contain pure patches from Halodule uninervis which covered more than $95 \%$ from the vegetated area. Stands 7 and 8 are with approximately depth $1.5 \pm 0.3 \mathrm{~m}$. The two stands contain three seagrasses species; H. stipulacea, H. uninervis and $H$. ovalis, the last species are found with few individuals. The cover of the $7^{\text {th }}$ and $8^{\text {th }}$ stands was about $40 \%$ of the vegetated area.

\section{General beach site.}

There was a symmetrical characterization in the habitat of this site in; sediment type, water depth and species diversity. Survey study showed that the $1^{\text {st }}$ stand in this site contain only one species (H. ovalis (R.Br.) Hook.f.) with low cover. The $2^{\text {nd }}$ stand contains two seagrasses species; $H$. stipulacea and $H$. ovalis where, $H$. ovalis segrass represented by few individuals. The $3^{\text {rd }}$ stand contains 2 seagrass species ( $H$. stipulacea and $H$. uninervis). $H$. stipulacea seagrass represents the main dominant species in this site. Syringodium isoetifolium (Forssk.) Hartog was recorded in winter and represented by one individual with good health. 
Aza'at site.

Stand 1 and stand 2 contain three seagrass species (H. stipulacea, $H$. uninervis and Th. ciliatum). In addition, stand 3 contained Th. ciliatum species only. Th. ciliatum seagrass represented the dominant species in this site and covered about $60-70 \%$ of the vegetated area.

Generally, five species were recorded in the studied sites Fig 2 and Table 2 showed that 6 stands contain 3 species and others contain 2 species while 5 stands contain 1 species. NIOF and General Beach sites contain 4 species while the other two sites contain three species. H. stipulacea is the dominant seagrass in the studied sites where it was recorded in the four sites and frequented by $70.6 \%$. In addition, $H$. unnerves is recorded in the four sites but with frequency 52.9\%. Th. ciliatum and H. ovalis were recorded in Abu shaar, NIOF and Aza'at sites with frequencies 52.9 and $23.5 \%$, respectively. On the other hand, Syringodium isoetifolium was represented by one individual in the $3^{\text {rd }}$ stand of General Beach in Safaga.

The dendrogam in Fig. 3. showed that the cluster is divided to two main subclusters subsequently each subcluster divided to two groups. Group 1 contains 8 stands (the three stands of Abu Shaar, those of Aza'at and the $1^{\text {st }} \& 2^{\text {nd }}$ of NIOF), these stands mainly dominated by H. stipulacea and Th. Ciliatum. The second group contains 6 stands $\left(3^{\text {rd }}, 4^{\text {th }}, 7^{\text {th }}\right.$ and $8^{\text {th }}$ stand of NIOF and the $1^{\text {st }} \&$ $2^{\text {nd }}$ stand of General beach) where H. stipulacea, H. uninervis and H. ovalis were recorded. Group 4 contains only one stand ( $3^{\text {rd }}$ stand of General Beach) where it's the unique stand which contains the seagrass Syringodium isoetifolium beside H. stipulacea and H. uninervis.

\section{Water analysis}

Water analysis data represents the mean values of summer and winter samples. Generally, Table 3. shows that there was low significant difference between physico-chemical properties of water in the four sites. Water of the four sites is alkaline where, their $\mathrm{pH}$ ranged between $8.2 \pm 0.2$ and $8.5 \pm 0.3$. pH, EC, salinity and $\mathrm{NaCl}$ of Hurghada water samples is significantly higher than those of Safaga water samples.

Anions content $\left(\mathrm{Cl}^{-}, \mathrm{HCO}_{3}{ }^{-}, \mathrm{CO}_{3}{ }^{2-}\right.$ and $\left.\mathrm{SO}_{4}{ }^{2-}\right)$ of the water samples showed low significant difference between the four sites. The data in Table 2 indicated that $\mathrm{HCO}_{3}{ }^{-}$and $\mathrm{CO}_{3}{ }^{2-}$ were recorded with very low concentrations in the sea water while $\mathrm{Cl}^{-}$and $\mathrm{SO}_{4}{ }^{2-}$ ions represented the main dominant anions. The highest concentrations of $\mathrm{Cl}^{-}$were recorded in Abu Shaar and NIOF (576.1 \pm 25.8 and 581.4 $\pm 45.7 \mathrm{meqL}^{-1}$, respectively), while $\mathrm{SO}_{4}{ }^{2-}$ recorded its highest concentration in General Beach and Aza'at $\left(960 \pm 288\right.$ and $955 \pm 364 \mathrm{meqL}^{-1}$, respectively). Sodium ions represent the main dominant cation in sea water, its highest concentration were recoded in NIOF $\left(1374 \pm 450 \mathrm{meqL}^{-1}\right)$ and its lowest concentration in Aza'at site $\left(1325 \pm 428 \mathrm{meqL}^{-1}\right)$. 
It is noticeable that $\mathrm{Na}^{+}, \mathrm{K}^{+}, \mathrm{Ca}^{++}$and $\mathrm{Mg}^{++}$concentrations are significantly higher in water of Abu Shaar and NIOF site than those of General Beach and Aza'at sites. Water samples of the four sites contain low concentrations of heavy metals; $\mathrm{Cd}, \mathrm{Cu}, \mathrm{Zn}, \mathrm{B}, \mathrm{Al}$ and $\mathrm{Fe}$ (Table 2). In addition there were no significant differences in their contents among the four sites. On the other hand, $\mathrm{Zn}$ and $\mathrm{B}$ recorded their highest concentrations in water of Aza'at site (0.0150 and 4.208 meqL $L^{-1}$, respectively).

The dendrogram Fig. 4 showed that the four sites were divided to two groups. The $1^{\text {st }}$ contained Abu Sha'ar and NIOF sites, while the $2^{\text {nd }}$ one contained General Beach and Aza'at sites. Meanwhile, there was high similarity coefficient among the four sites.

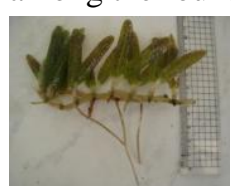

H. stipulacea

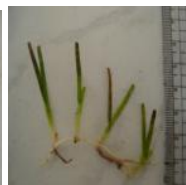

H. uninervis

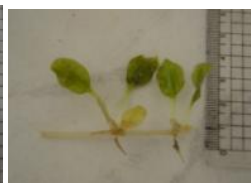

H. ovalis

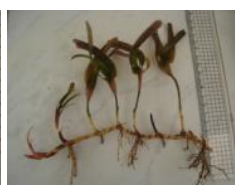

Th. Ciliatum

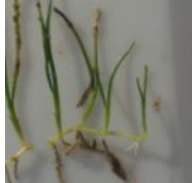

S. isoetifolium

Fig. 2 Photographs of seagrasses species recoded in the studied sites.

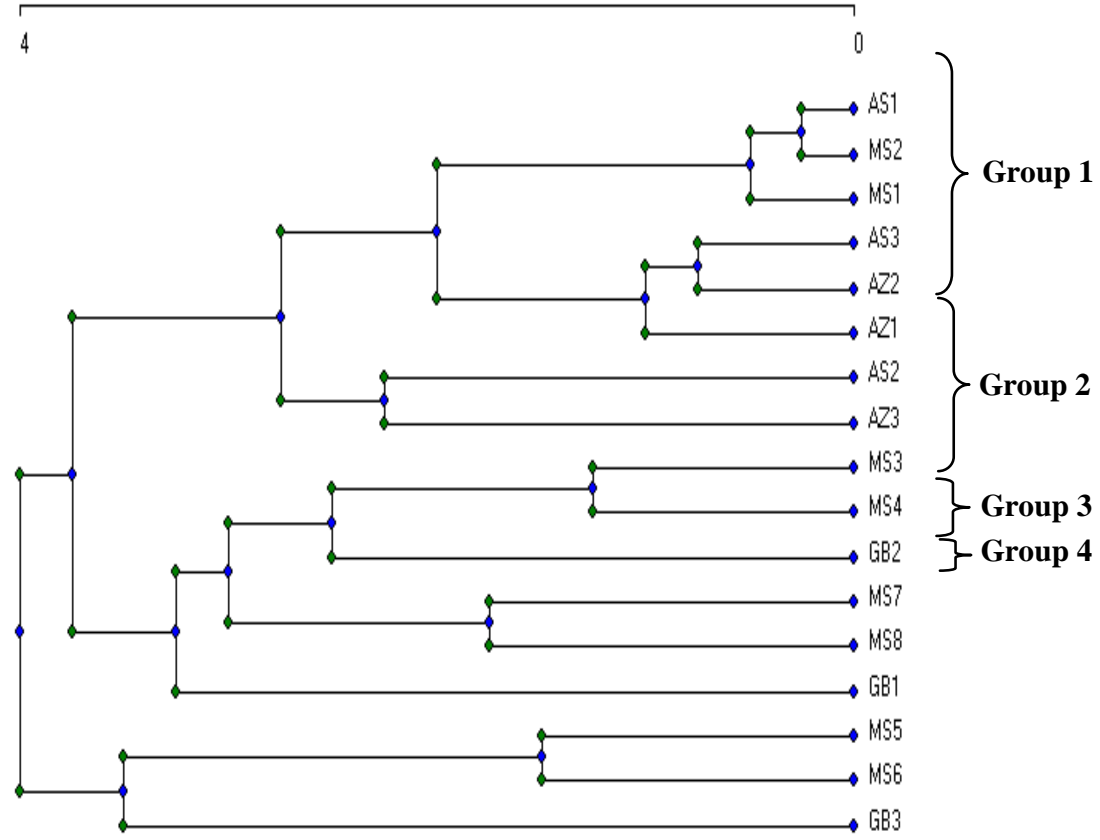

Fig. 3. Dendrogram resulted from agglomerative clustering technique based on seagrasses composition for 17 seagrasses stands in four stands located at Hurgada and Safaga. 
TABLE 2. Distribution of seagrasses species and their frequencies in four sites located at Horgada and Safaga, Red Sea coast according to absence (0) or presence (1) in summer and winter seasons

\begin{tabular}{|c|c|c|c|c|c|c|c|c|c|c|c|c|c|c|c|c|c|c|}
\hline & \multicolumn{3}{|c|}{ Abu Shaar } & \multicolumn{8}{|c|}{ NIOF } & \multicolumn{3}{|c|}{ General Beach } & \multicolumn{3}{|c|}{ Aza'at } & Species \\
\hline & $\begin{array}{c}\text { AS } \\
1 \\
\end{array}$ & $\begin{array}{c}\text { AS } \\
2\end{array}$ & $\begin{array}{c}\text { AS } \\
3\end{array}$ & $\begin{array}{c}\text { MS } \\
1 \\
\end{array}$ & $\begin{array}{c}\text { MS } \\
2 \\
\end{array}$ & $\begin{array}{c}\text { MS } \\
3 \\
\end{array}$ & $\begin{array}{c}\text { MS } \\
4 \\
\end{array}$ & $\begin{array}{c}\text { MS } \\
5 \\
\end{array}$ & $\begin{array}{c}\text { MS } \\
6 \\
\end{array}$ & $\begin{array}{c}\text { MS } \\
7\end{array}$ & $\begin{array}{c}\text { MS } \\
8 \\
\end{array}$ & $\begin{array}{c}\mathrm{GB} \\
1 \\
\end{array}$ & $\begin{array}{c}\mathrm{GB} \\
2 \\
\end{array}$ & $\begin{array}{c}\text { GB } \\
3 \\
\end{array}$ & $\begin{array}{c}Z A \\
1 \\
\end{array}$ & $\begin{array}{c}A Z \\
2 \\
\end{array}$ & $\begin{array}{c}\mathrm{A} Z \\
3 \\
\end{array}$ & $\begin{array}{c}\text { Frequency } \\
\%\end{array}$ \\
\hline H. stipulacea & 1 & 0 & 1 & 1 & 1 & 1 & 1 & 0 & 0 & 1 & 1 & 0 & 1 & 1 & 1 & 1 & 0 & 70.6 \\
\hline H. uninervis & 0 & 1 & 1 & 0 & 0 & 0 & 0 & 1 & 1 & 1 & 1 & 0 & 0 & 1 & 1 & 1 & 0 & 52.9 \\
\hline H. ovalis & 0 & 0 & 0 & 0 & 0 & 0 & 0 & 0 & 0 & 1 & 1 & 1 & 1 & 0 & 0 & 0 & 0 & 23.5 \\
\hline Th. Ciliatum & 1 & 1 & 1 & 1 & 1 & 0 & 0 & 0 & 0 & 0 & 0 & 0 & 0 & 0 & 1 & 1 & 1 & 47.1 \\
\hline $\begin{array}{l}\text { Syringodium } \\
\text { isoetifolium }\end{array}$ & 0 & 0 & 0 & 0 & 0 & 0 & 0 & 0 & 0 & 0 & 0 & 0 & 0 & 1 & 0 & 0 & 0 & 5.9 \\
\hline $\begin{array}{l}\text { No. of sp. in } \\
\text { stand }\end{array}$ & 2 & 2 & 3 & 2 & 2 & 2 & 1 & 1 & 1 & 3 & 3 & 1 & 2 & 3 & 3 & 3 & 1 & \\
\hline $\begin{array}{l}\text { No. of sp. in } \\
\text { site }\end{array}$ & & 3 & & & & & & & & & & & 4 & & & 3 & & \\
\hline
\end{tabular}

Sediment analysis

Table 4 showed that the sediments of the 17 stands in the studied sites are mainly constructed from coarse and fine sand, where their highest percentages estimate, 92.4 and $92.7 \%$ in NIOF and Aza'at sites respectively. While their lowest percentages estimate, 88.7 and 90.5 in Abu Shaar and General Beach sites respectively. Gravel, silt and clay granules are found with low percentages in the sediment of the studied stands. Gravel recorded its highest percentage in General Beach site $(3.1 \pm 0.48 \%)$ but the lowest percentage were recorded in Abu Shaar $(1.0 \pm 0.14 \%)$. the highest percentage of silt was recorded in Abu Shaar site $(7.6 \pm 0.66 \%)$ and that of clay was recorded in General Beach $(2.3 \pm 0.180 \%)$.

Dendrogram in Fig. 5 showed that the 17 stands were divided to 2 groups. The first group consists of 9 stands; the three stands of Abu Shaar and those of Aza'at and the first three stands of NIOF, where these stands contain coarse sand more than fine sand. While the second group consists of 8 stands; the three stands of General Beach and the $4^{\text {th }}, 5^{\text {th }}, 6^{\text {th }}, 7^{\text {th }}$ and $8^{\text {th }}$ stand of NIOF, where these stands contains of fine sand more than coarse sand.

Stands of NIOF and General Beach recorded the highest values of organic matter which ranged between $3.4 \pm 0.31-4.8 \pm 0.36 \%$ in NIOF site and 2.9 \pm 0.26 $3.4 \pm 0.32 \%$ in the General Beach. Noticeably, the sediment organic matter content slightly differed among stands within the same site but clearly differed among the four Sites (Table 4). 
TABLE 3. Physico-chemical properties of four sites water in located at Hurgada and

\begin{tabular}{|c|c|c|c|c|c|}
\hline & & Abu Shaar & NIOF & General Beach & Aza'at \\
\hline $\mathrm{pH}$ & & $8.5 a \pm 0.3$ & $8.5 a \pm 0.2$ & $8.2 b \pm 0.2$ & $8.3 b \pm 0.3$ \\
\hline $\mathrm{EC}\left(\mathrm{dS} \mathrm{m}^{-1}\right.$ & & $70.9 a \pm 5.2$ & $68.3 a \pm 3.8$ & $66.4 \mathrm{~b} \pm 4.5$ & $67.4 \mathrm{ab} \pm 5.1$ \\
\hline TSS & \multirow{3}{*}{ בד. } & $44.4 \mathrm{a} \pm 4.5$ & $44.8 \mathrm{a} \pm 6.5$ & $43.6 \mathrm{a} \pm 3.7$ & $43.2 \mathrm{a} \pm 4.8$ \\
\hline Salinity & & $36.7 \mathrm{a} \pm 3.7$ & $36.4 \mathrm{a} \pm 4.4$ & $34.4 b \pm 6.5$ & $35.7 \mathrm{a} \pm 5.2$ \\
\hline $\mathrm{NaCl}$ & & $33.9 a \pm 5.8$ & $34.1 \mathrm{a} \pm 6.8$ & $33.4 a \pm 4.6$ & $32.1 \mathrm{~b} \pm 3.9$ \\
\hline \multicolumn{6}{|c|}{ Anions } \\
\hline $\mathrm{Cl}^{-}$ & \multirow{9}{*}{ تَّ } & $576.1 \mathrm{a} \pm 25.8$ & $581.4 \mathrm{a} \pm 45.7$ & $567.9 \mathrm{a} \pm 33.7$ & $570.4 a \pm 28.7$ \\
\hline $\mathrm{HCO}_{3}{ }^{-}$ & & $5.50 \mathrm{a} \pm 2.4$ & $5.00 \mathrm{a} \pm 1.02$ & $4.75 \mathrm{a} \pm 1.45$ & $4.35 \mathrm{a} \pm 0.88$ \\
\hline $\mathrm{CO}_{3}{ }^{2-}$ & & $1.9 \mathrm{a} \pm 0.6$ & $1.7 \mathrm{ab} \pm 0.4$ & $1.3 b \pm 0.4$ & $1.5 b \pm 0.6$ \\
\hline $\mathrm{SO}_{4}^{2-}$ & & $894 b \pm 245$ & $937 a \pm 164$ & $960 \mathrm{a} \pm 288$ & $955 a \pm 364$ \\
\hline Cations & & & & & \\
\hline $\mathrm{Na}^{+}$ & & $1374 a \pm 450$ & $1376 \mathrm{a} \pm 385$ & $1338 \mathrm{a} \pm 255$ & $1325 \mathrm{a} \pm 428$ \\
\hline $\mathrm{K}^{+}$ & & $50.0 \mathrm{a} \pm 8.7$ & $48.2 \mathrm{a} \pm 5.6$ & $45.3 \mathrm{a} \pm 10.8$ & $44.7 \mathrm{a} \pm 6.78$ \\
\hline $\mathrm{Ca}^{++}$ & & $23.8 \mathrm{a} \pm 4.7$ & $24.2 \mathrm{a} \pm 3.5$ & $23.2 \mathrm{a} \pm 4.5$ & $23.2 \mathrm{a} \pm 2.6$ \\
\hline $\mathrm{Mg}^{++}$ & & $89.2 \mathrm{a} \pm 12.7$ & $91.6 \mathrm{a} \pm 18.6$ & $84.2 b \pm 15.6$ & $85.8 \mathrm{~b} \pm 10.8$ \\
\hline \multicolumn{6}{|c|}{ Heavy metal } \\
\hline $\mathrm{Cd}$ & \multirow{7}{*}{ 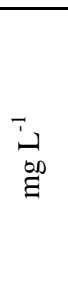 } & $<0.0005$ & $<0.0005$ & $<0.0005$ & $<0.0005$ \\
\hline $\mathrm{Cu}$ & & $<0.006$ & $<0.006$ & $<0.006$ & $<0.006$ \\
\hline $\mathrm{Mn}$ & & $<0.001$ & $<0.001$ & $<0.001$ & $<0.001$ \\
\hline $\mathrm{Zn}$ & & $0.0032 \mathrm{~b}$ & $0.0037 \mathrm{~b}$ & $0.0063 \mathrm{~b}$ & $0.0150 \mathrm{a}$ \\
\hline $\mathrm{B}$ & & $4.122 \mathrm{~d}$ & $4.187 \mathrm{~b}$ & $4.153 \mathrm{c}$ & $4.208 \mathrm{a}$ \\
\hline $\mathrm{Al}$ & & 0.054 & 0.057 & 0.043 & 0.047 \\
\hline $\mathrm{Fe}$ & & $<0.001$ & $<0.001$ & $<0.001$ & $<0.001$ \\
\hline
\end{tabular}

Values in the same raw with the same letter in not significant different at $\mathrm{p}<0.05$
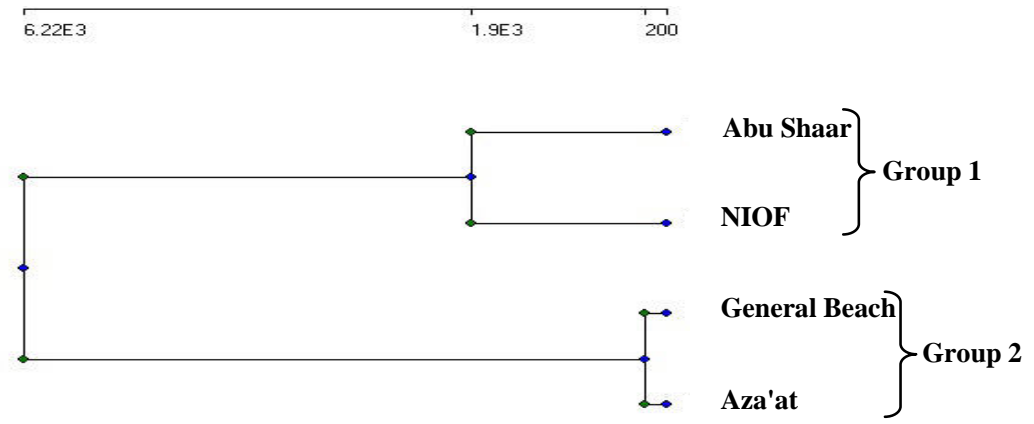

Fig. 4. Dendrogram of four sites resulted from agglomerative clustering technique based on physico-chemical properties of sea water. 


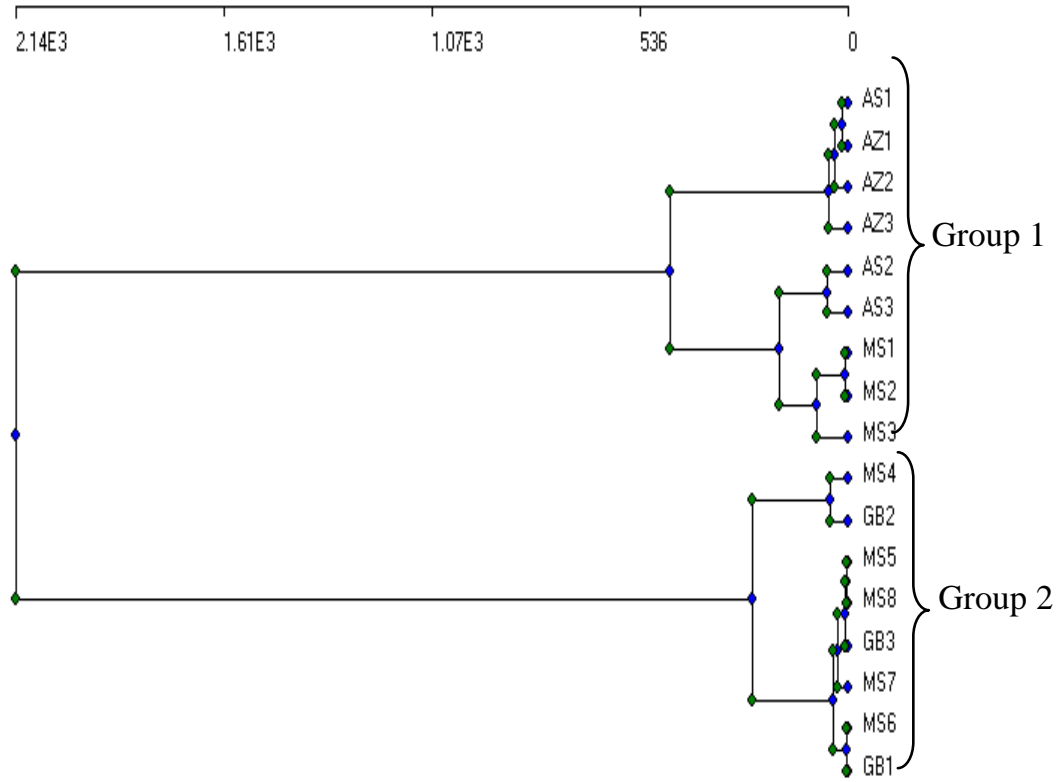

Fig. 5. Dendrogram of 17 stands of 17 seagrass stands located at 4 sites in Hurgada and Safaga based on sediment texture (AS: Abu Shaar; MS: NIOF; GB: General Beach and Az: Aza'at site).

TABLE 4. Sediment analysis of 17 seagrass stands located at 4 sites in Hurgada and Safaga

\begin{tabular}{|c|c|c|c|c|c|c|c|c|}
\hline Sites & Stands & Gravel & $\begin{array}{l}\text { Coarse } \\
\text { sand \% }\end{array}$ & $\begin{array}{c}\text { Fine sand } \\
\%\end{array}$ & Silt \% & Clay \% & $\begin{array}{l}\text { Organic } \\
\text { mater \% }\end{array}$ & $\begin{array}{c}\mathrm{CaCO}_{3} \\
\% \\
\end{array}$ \\
\hline \multirow{4}{*}{ 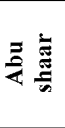 } & AS1 & $0.3 \pm 0.04$ & $59.3 \pm 5.32$ & $32.0 \pm 3.65$ & $8.2 \pm 0.65$ & $0.2 \pm 0.014$ & $2.0 \pm 0.18$ & $32.0 \pm 2.85$ \\
\hline & AS2 & $0.6 \pm 0.05$ & $54.0 \pm 4.65$ & $36.0 \pm 4.15$ & $9.0 \pm 0.80$ & $0.4 \pm 0.032$ & $1.9 \pm 0.14$ & $33.8 \pm 3.11$ \\
\hline & AS3 & $2.1 \pm 0.32$ & $49.8 \pm 4.11$ & $37.9 \pm 3.8$ & $5.6 \pm 0.52$ & $4.6 \pm 0.38$ & $1.6 \pm 0.14$ & $31.8 \pm 2.65$ \\
\hline & Mean & $1.0 \pm 0.14$ & $54.4 \pm 4.69$ & $35.3 \pm 3.87$ & $7.6 \pm 0.66$ & $1.7 \pm 0.14$ & $1.8 \pm 0.15$ & $32.5 \pm 2.87$ \\
\hline \multirow{9}{*}{$\frac{\sqrt[5]{0}}{\frac{6}{2}}$} & MS1 & $1.0 \pm 0.09$ & $52.7 \pm 1.05$ & $43.2 \pm 6.85$ & $3.1 \pm 0.28$ & $0.9 \pm 0.082$ & $4.8 \pm 0.36$ & $32.8 \pm 2.76$ \\
\hline & MS2 & $1.3 \pm 0.12$ & $53.2 \pm 1.32$ & $40.5 \pm 5.98$ & $3.8 \pm 0.34$ & $1.2 \pm 0.096$ & $3.4 \pm 0.31$ & $30.4 \pm 2.65$ \\
\hline & MS3 & $2.6 \pm 0.45$ & $46.2 \pm 3.56$ & $46.2 \pm 4.08$ & $3.6 \pm 0.32$ & $1.4 \pm 0.032$ & $4.2 \pm 0.38$ & $30.8 \pm 2.74$ \\
\hline & MS4 & $0.8 \pm 0.07$ & $28.6 \pm 2.14$ & $62.6 \pm 5.62$ & $6.8 \pm 0.58$ & $1.2 \pm 0.110$ & $3.9 \pm 0.34$ & $32.5 \pm 3.12$ \\
\hline & MS5 & $2.4 \pm 0.30$ & $36.8 \pm 2.98$ & $53.2 \pm 5.14$ & $4.9 \pm 0.42$ & $2.5 \pm 0.260$ & $3.6 \pm 0.32$ & $28.5 \pm 2.64$ \\
\hline & MS6 & $2.6 \pm 0.03$ & $35.4 \pm 2.67$ & $54.6 \pm 6.32$ & $5.2 \pm 0.64$ & $2.3 \pm 0.210$ & $4.0 \pm 0.36$ & $31.2 \pm 2.93$ \\
\hline & MS7 & $1.9 \pm 0.22$ & $39.3 \pm 3.56$ & $55.2 \pm 5.28$ & $2.4 \pm 0.22$ & $1.2 \pm 0.140$ & $3.8 \pm 0.33$ & $29.5 \pm 2.75$ \\
\hline & MS8 & $2.2 \pm 0.17$ & $38.2 \pm 3.78$ & $53.6 \pm 5.19$ & $3.7 \pm 0.36$ & $2.3 \pm 0.180$ & $3.7 \pm 0.35$ & $30.2 \pm 2.85$ \\
\hline & Mean & $1.9 \pm 0.18$ & $41.3 \pm 3.64$ & $51.1 \pm 5.55$ & $4.2 \pm 0.36$ & $1.5 \pm 0.139$ & $3.9 \pm 0.35$ & $30.7 \pm 2.81$ \\
\hline \multirow{4}{*}{ 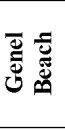 } & GB1 & $3.0 \pm 0.95$ & $36.5 \pm 2.14$ & $54.0 \pm 4.33$ & $5.7 \pm 0.47$ & $1.0 \pm 0.080$ & $3.4 \pm 0.32$ & $45.0 \pm 4.25$ \\
\hline & GB2 & $3.5 \pm 0.26$ & $31.6 \pm 0.96$ & $59.8 \pm 7.62$ & $2.4 \pm 0.23$ & $2.5 \pm 0.196$ & $2.9 \pm 0.26$ & $42.5 \pm 3.65$ \\
\hline & GB3 & $2.8 \pm 0.23$ & $38.5 \pm 2.85$ & $51.0 \pm 4.56$ & $4.5 \pm 0.42$ & $3.5 \pm 0.265$ & $3.3 \pm 0.29$ & $46.7 \pm 4.38$ \\
\hline & Mean & $3.1 \pm 0.48$ & $35.5 \pm 1.98$ & $54.9 \pm 5.50$ & $4.2 \pm 0.37$ & $2.3 \pm 0.180$ & $3.2 \pm 0.29$ & $44.7 \pm 4.09$ \\
\hline \multirow{4}{*}{ 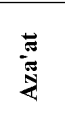 } & AZ1 & $1.2 \pm 0.11$ & $57.0 \pm 4.52$ & $33.7 \pm 3.12$ & $6.0 \pm 0.52$ & $2.0 \pm 0.196$ & $2.7 \pm 0.25$ & $39.0 \pm 3.62$ \\
\hline & $\mathbf{A Z 2}$ & $1.0 \pm 0.08$ & $62.0 \pm 5.68$ & $30.6 \pm 2.85$ & $5.0 \pm 0.46$ & $1.5 \pm 0.112$ & $1.9 \pm 0.15$ & $42.2 \pm 4.18$ \\
\hline & AZ3 & $1.2 \pm 0.09$ & $58.7 \pm 3.72$ & $36.2 \pm 4.16$ & $2.5 \pm 0.22$ & $1.5 \pm 0.032$ & $2.0 \pm 0.17$ & $41.5 \pm 3.95$ \\
\hline & Mean & $1.1 \pm 0.09$ & $59.2 \pm 4.64$ & $33.5 \pm 3.38$ & $4.5 \pm 0.40$ & $1.7 \pm 0.113$ & $2.2 \pm 0.19$ & $40.9 \pm 3.92$ \\
\hline
\end{tabular}

Egypt. J. Bot., 56, No. 1 (2016) 
The present data showed homogeneous distribution to calcium carbonate in the stands of the same site (table 4). Calcium carbonate recorded its lowest values in Abu Shaar and NIOF (32.5 \pm 2.87 and $30.7 \pm 2.81 \%$, respectively) but it recorded its highest values in General Beach and Aza'at (44.7 $\pm 4.09-40.9 \pm 3.92 \%$, respectively).

\section{Seagrasses density and biomass}

Generally, Table 5 showed that the density and biomass means of seagrasses; H. stipulacea, $H$. ovalis and Th. ciliatum were significantly increased in summer compared with winter season but conversely occurred with $H$. uninervis. In addition, there is significant variation among density and biomass means of each seagrass in the four sites. The presented data indicated that $H$. stipulacea recorded its highest density and biomass in NIOF site with annual mean 588.9 shoot $/ \mathrm{m}^{2}$ and $12.82 \mathrm{~g} / \mathrm{m}^{2}$ respectively, while its lowest annual mean was recorded in Aza'at site (176.5 shoot $/ \mathrm{m}^{2}$ and $2.56 \mathrm{~g} / \mathrm{m}^{2}$ respectively). The annual mean of density and biomass of $H$. uninervis is followed the order; NIOF (1386 leaf pairs $\mathrm{m}^{-2}$ and $\left.41.7 \mathrm{gm}^{-2}\right)>$ Aza'at $\left(141\right.$ leaf pairs $/ \mathrm{m}^{2}$ and $\left.4.73 \mathrm{~g} / \mathrm{m}^{2}\right)>\mathrm{Abu}$ Shaar $\left(48.4\right.$ leaf pairs $/ \mathrm{m}^{2}$ and $\left.2.61 \mathrm{~g} / \mathrm{m}^{2}\right)>$ General Beach $\left(31.6\right.$ leaf pairs $/ \mathrm{m}^{2}$ and $\left.1.18 \mathrm{~g} / \mathrm{m}^{2}\right)$. H. ovalis grow with high annual mean density $\left(60.9 \mathrm{shoot} / \mathrm{m}^{2}\right)$ and biomass $\left(0.268 \mathrm{~g} / \mathrm{m}^{2}\right)$ in General Beach site but in NIOF site it was recorded with few individuals and low biomass. Th. Ciliatum seagrass recorded its highest annual mean of density and biomass in Abu Shaar site $\left(209.9\right.$ shoot $/ \mathrm{m}^{2}$ and 50.8 $\mathrm{g} / \mathrm{m}^{2}$ respectively) but its lowest annual mean recorded in NIOF site (100.6 shoot/ $\mathrm{m}^{2}$ and $16.01 \mathrm{~g} / \mathrm{m}^{2}$ respectively).

\section{Photosynthetic pigments}

Figure. $6 \mathrm{a}$ and $\mathrm{b}$ showed that $\operatorname{chl} a$ content of $H$. stipulacea and chl $a \& \operatorname{chl} b$ content of $H$. uninervis seagrasses significantly increased in winter than in summer in the four sites. On the other hand, chl $b$ of $H$. stipulacea and chl $a \&$ chl $b$ of $H$. ovalis and Th. ciliatum significantly increased in winter than in summer. Chl $a \&$ chl $b$ content of $H$. stipulacea and H. uninervis seagrasses recorded their highest content in NIOF site (5.67 and $3.09 \mathrm{mgg}_{-}{ }^{1}$ fresh wt, respectively), while their lowest content were recorded in Aza'at site for $H$. stipulacea (2.57 $\mathrm{mgg}_{-}{ }^{1}$ fresh wt) and in General Beach for H. uninervis (4.01 mgg- ${ }^{1}$ fresh wt). The highest $\operatorname{chl} a$ and chl $b$ contents were recorded in General Beach site for H. ovalis and in Abu Shaar site for Th. Ciliatum seagrass.

Low significant variation in carotenoids content of the 4 seagrasses in the four sites during the two seasons was shown by fig (6c). Generally, carotenoids content recorded their highest values in winter. The highest carotenoids content was recorded in; Abu Shaar sites for $H$. stipulacea $\left(2.75 \pm 0.18 \mathrm{mgg}^{-1}\right)$, NIOF site for H. uninervis $\left(4.24 \pm 0.16 \mathrm{mgg}^{-1}\right)$, General Beach site for H. ovalis $(3.2 \pm 0.17$ $\left.\mathrm{mgg}^{-1}\right)$ and Aza'at site for Th. Ciliatum $\left(3.11 \pm 0.15 \mathrm{mgg}^{-1}\right)$. 
TABLE 5. Biomass and density (means \pm SE) of four seagrasses during summer and winter seasons in 4 sites at Hurghada and Safaga, Red Sea Coast. (AS: Abu Shaar; MS: NIOF; GB: General Beach and Az: Aza'at site)

\begin{tabular}{|c|c|c|c|c|c|}
\hline \multirow[t]{2}{*}{ Spesies } & \multirow[t]{2}{*}{ Site } & \multicolumn{2}{|c|}{$\operatorname{Biomass}\left(\mathrm{g} / \mathrm{m}^{2}\right)$} & \multicolumn{2}{|c|}{$\begin{array}{c}\text { Density (shoot or leaf } \\
\text { pairs } / \mathbf{m}^{2} \text { ) }\end{array}$} \\
\hline & & Summer & Winter & Summer & Winter \\
\hline \multirow{4}{*}{$\begin{array}{l}H . \\
\text { stipulacea }\end{array}$} & AS & $255.0 \pm 10.18$ & $222.17 \pm 10.23$ & $7.18 \pm 0.50$ & $4.77 \pm 0.30$ \\
\hline & MS & $588.9 \pm 20.29$ & $309.6 \pm 10.16$ & $13.49 \pm 1.02$ & $12.14 \pm 0.90$ \\
\hline & GB & $293.3 \pm 10.16$ & $280.0 \pm 15.11$ & $11.64 \pm 1.20$ & $7.02 \pm 0.20$ \\
\hline & $\mathrm{Az}$ & $182.9 \pm 12.29$ & $170.0 \pm 9.03$ & $2.98 \pm 0.13$ & $2.14 \pm 0.13$ \\
\hline \multicolumn{2}{|c|}{ LSD at $5 \%$ for } & \multicolumn{2}{|c|}{ Sites $\rightarrow 6.36$; easones $\rightarrow 10.57$} & \multicolumn{2}{|c|}{ Sites $\rightarrow 2.25$; Seasones $\rightarrow 1.30$} \\
\hline \multirow{4}{*}{ H. uninervis } & $\mathrm{AS}$ & $44.1 \pm 1.17$ & $52.6 \pm 2.17$ & $2.34 \pm 0.14$ & $2.88 \pm 0.21$ \\
\hline & MS & $1261.5 \pm 90.39$ & $1510.5 \pm 180.29$ & $35.60 \pm 3.01$ & $47.7 \pm 3.62$ \\
\hline & GB & $25.2 \pm 3.27$ & $37.8 \pm 2.28$ & $1.16 \pm 0.12$ & $1.20 \pm 0.13$ \\
\hline & $\mathrm{Az}$ & $126.5 \pm 2.06$ & $155.5 \pm 10.28$ & $4.17 \pm 0.21$ & $5.29 \pm 0.32$ \\
\hline \multicolumn{2}{|c|}{ LSD at $5 \%$ for } & \multicolumn{2}{|c|}{ Sites $\rightarrow 45.20 ;$ easones $\rightarrow 6.58$} & \multicolumn{2}{|c|}{ Sites $\rightarrow 1.11 ;$ Seasones $\rightarrow 2.45$} \\
\hline \multirow{4}{*}{ H. ovalis } & AS & - & - & - & - \\
\hline & MS & $15.5 \pm 1.0$ & $12.3 \pm 1.01$ & $0.058 \pm 0.001$ & $0.051 \pm 0.01$ \\
\hline & GB & $65.9 \pm 0.10$ & $55.9 \pm 4.25$ & $0.296 \pm 0.03$ & $0.240 \pm 0.01$ \\
\hline & $\mathrm{Az}$ & - & - & - & - \\
\hline \multicolumn{2}{|c|}{ LSD at $5 \%$ for } & \multicolumn{2}{|c|}{ Sites $\rightarrow 8.62 ;$ Seasones $\rightarrow 5.48$} & \multicolumn{2}{|c|}{$\begin{array}{c}\text { Sites } \rightarrow 0.011 ; \\
\text { Seasones } \rightarrow 0.045\end{array}$} \\
\hline \multirow{4}{*}{$\begin{array}{l}\text { Th. } \\
\text { Ciliatum }\end{array}$} & AS & $237.0 \pm 4.18$ & $182.9 \pm 10.28$ & $58.37 \pm 4.16$ & $43.23 \pm 3.11$ \\
\hline & MS & $102.2 \pm 13.16$ & $98.9 \pm 6.11$ & $16.46 \pm 1.28$ & $15.56 \pm 1.18$ \\
\hline & GB & - & - & - & - \\
\hline & $\mathrm{Az}$ & $157.0 \pm 2.03$ & $112.2 \pm 2.01$ & $30.78 \pm 2.15$ & $23.00 \pm 1.37$ \\
\hline \multicolumn{2}{|c|}{ LSD at $5 \%$ for } & \multicolumn{2}{|c|}{ Sites $\rightarrow 15.42 ;$ Seasones $\rightarrow 12.7$} & \multicolumn{2}{|c|}{ Sites $\rightarrow 3.25$; Seasones $\rightarrow 8.42$} \\
\hline
\end{tabular}

Metabolic products

Carbohydrates content

The present data indicated that the studied four seagrasses have high contents of total carbohydrates and total soluble sugars. Fig. (7a) showed that total carbohydrates and total soluble sugars of $H$. stipulacea and $H$. uninervis seagrasses significantly increased in winter than in summer, while those of $H$. ovalis and Th. ciliatum showed significant increase in summer. $H$. stipulacea and $H$. uninervis recoded their highest total carbohydrates $(27.73 \pm 0.81$ and 40.30 $\mathrm{mgg}^{-1}$ dry wt respectively) and total soluble sugars (12.20 \pm 0.51 and $16.25 \pm 0.67$ $\mathrm{mgg}^{-1}$ fresh wt respectively) in NIOF site. On the other hand, H. ovalis recorded its highest content of total carbohydrates $\left(30.71 \pm 0.83 \mathrm{mgg}^{-1}\right.$ dry wt) and total soluble sugars $\left(9.61 \pm 0.83 \mathrm{mgg}^{-1}\right.$ fresh wt) in General Beach site in summer. Highest contents of total carbohydrates $\left(43.41 \pm 0.92 \mathrm{mgg}^{-1}\right.$ dry wt) and total soluble sugars $\left(17.48 \pm 1.15 \mathrm{mgg}^{-1}\right.$ fresh wt) of Th. Ciliatum were recorded in Aza'at site.

Egypt. J. Bot., 56, No. 1 (2016) 
a
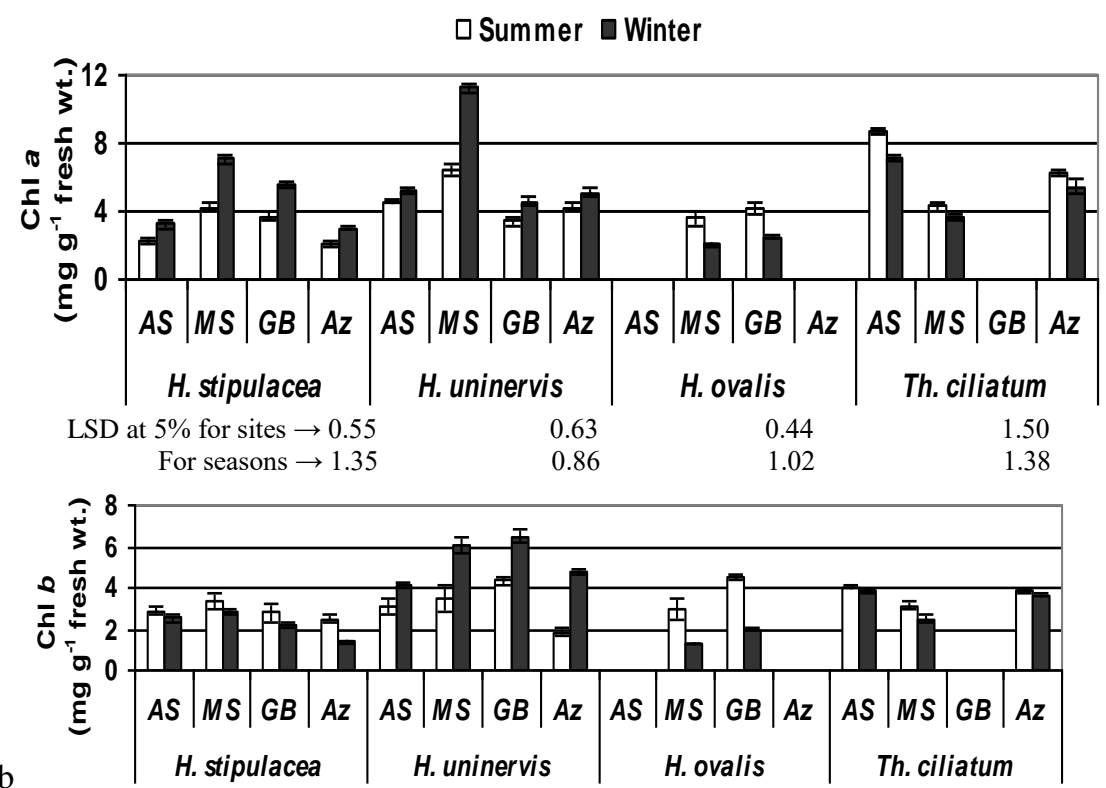
LSD at $5 \%$ for sites $\rightarrow 0.24$
0.54
0.56
0.62
For seasons $\rightarrow 0.36$
1.58
1.08
0.35

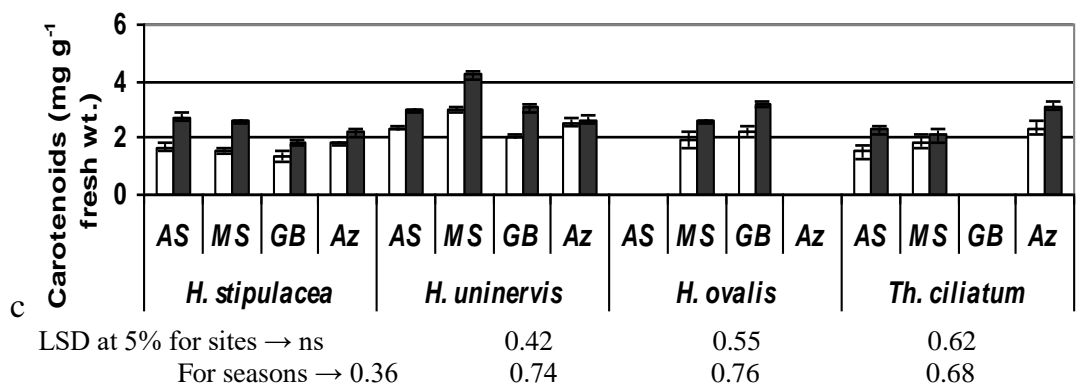

Fig. 6. Photosynthetic pigments content [a- Chlorophyll $a$, b- chlorophyll $b$ and ccarotenoids $\left.\left(\mathrm{mgg}^{-1}\right)\right]$ of four seagrasses species during summer and winter seasons in 4 sites at Hurghada and Safaga, Red Sea Coast. (AS: Abu Shaar; MS: Marine Station; GB: General Beach and Az: Aza'at site). 

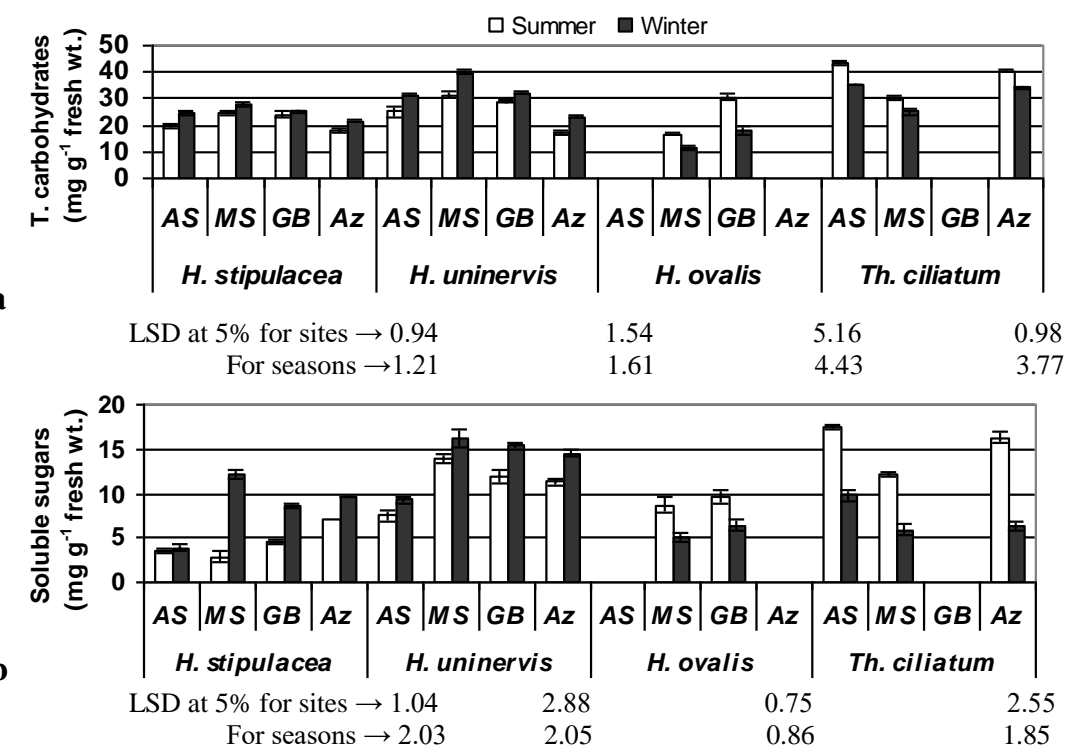

Fig. 7. a- Total carbohydrates $\left(\mathrm{mgg}^{-1} \mathrm{dry} w \mathrm{w}\right)$ and b- Soluble sugars $\left(\mathrm{mgg}^{-1}\right.$ fresh wt) contents of four seagrasses species during summer and winter seasons in 4 sites at Hurghada and Safaga, Red Sea Coast. (AS: Abu Shaar; MS: NIOF; GB: General Beach and Az: Aza'at site).

\section{Nitrogenous compounds}

Noticeably, Crude protein of the four seagrasses significantly increased in winter season than in summer season in the four studied sites (fig. 8a). The highest values of crude protein of $H$. stipulacea and $H$. uninervis were recorded in NIOF site $\left(67.3 \pm 1.41\right.$ and $105.0 \pm 1.43 \mathrm{mgg}^{-1}$ fresh wt. respectively). On the other hand, highest values of crude protein were recorded in General Beach site for $H$. ovalis $\left(95.94 \pm 1.42 \mathrm{mgg}^{-1}\right.$ fresh wt.) and in Aza'at site for Th. Ciliatum (91.88 $\pm 4.29 \mathrm{mgg}^{-1}$ fresh).

Figure $8 \mathrm{~b}, \mathrm{c}$ and $\mathrm{d}$ showed that the soluble protein, total free amino acids and proline contents significantly increased in summer comparing to winter season. In addition, the three compounds recorded their highest contents in NIOF site fo; $H$. stipulacea $\left(62.12 \pm 1.5,35.39 \pm 0.66\right.$ and $5.97 \pm 0.29 \mathrm{mgg}^{-1}$ fresh wt. respectively), H. uninervis $\left(58.86 \pm 1.51,42.53 \pm 0.96\right.$ and $7.50 \pm 0.11 \mathrm{mgg}^{-1}$ fresh wt. respectively) and Th. Ciliatum $\left(56.1 \pm 1.76,25.08 \pm 0.56\right.$ and $5.10 \pm 0.104 \mathrm{mgg}^{-1}$ fresh wt. respectively). On the other hand, the highest contents of soluble protein, total free amino acids and proline of $H$. ovalis were recorded in General Beach site. 

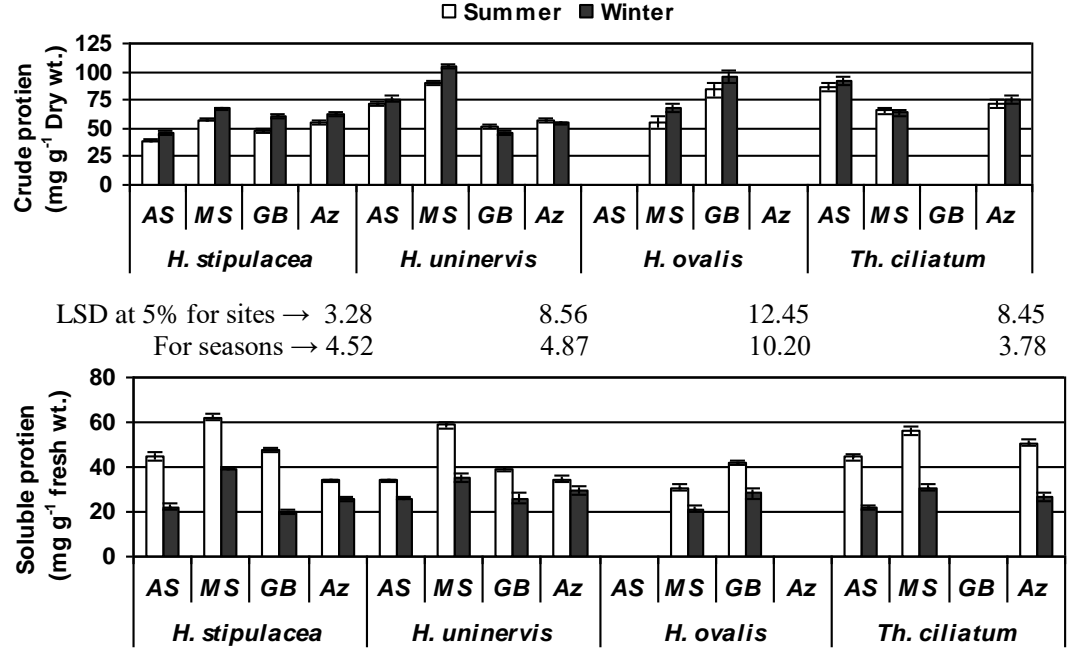

b

LSD at $5 \%$ for sites $\rightarrow 2.65$

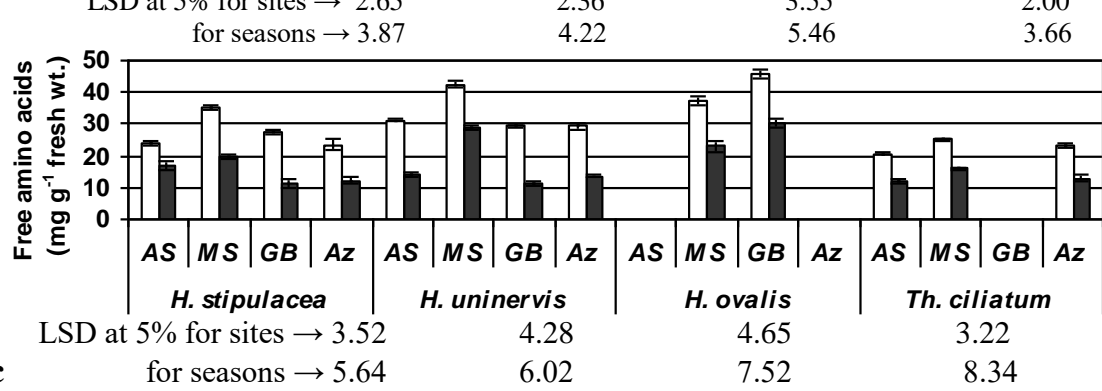

c

for seasons $\rightarrow 5.64$

6.02

7.52

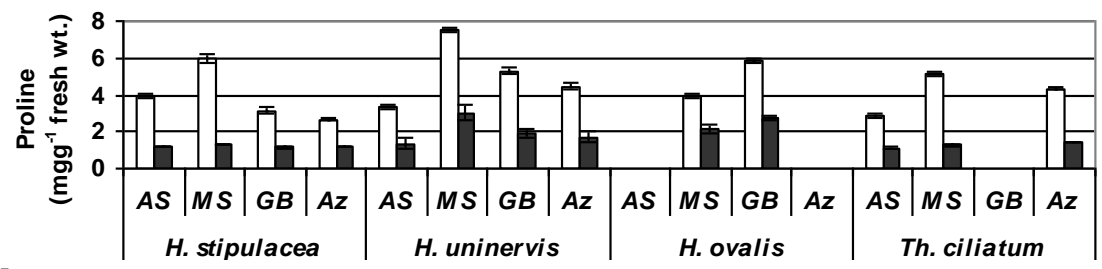

d
LSD at $5 \%$ for sites $\rightarrow 1.22$
for seasons $\rightarrow 1.14$
1.08
2.44
1.65
0.65
1.36

Fig. 8. a-Crude protein, b- Soluble protein, c- Free amino acids and d- Proline contents of four seagrasses species during summer and winter seasons in 4 sites at Hurghada and Safaga, Red Sea Coast. (AS: Abu Shaar; MS: NIOF; GB: General Beach and Az: Aza'at site).

\section{Minerals content}

Table 6 shows that nitrogen content of the four seagrasses increased in winter season than in summer season in the four studied sites. Generally, nitrogen of $H$. 
stipulacea, $H$. uninervis and $H$. ovalis recorded its highest content in NIOF site, but Th. ciliatum recorded its highest content in Abu Shaar site. On the other hand, the lowest nitrogen contents were recorded in Abu Shaar site for $H$. stipulacea, in General Beach site for H. uninervis \& H. ovalis and in NIOF site for Th. ciliatum.

Statistically, phosphorus contents of the four seagrasses were significantly affected by seasonality and by their geographical distribution. Table 6 showed that phosphorus contents of $H$. stipulacea and $H$. uninervis significantly increased in summer than in winter, while $\mathrm{P}$ content of $H$. ovalis and Th. ciliatum significantly increased in winter than in summer. The highest value of phosphorus content of $H$. stipulacea was recorded in NIOF site, while that of $H$. uninervis and $H$. ovalis was in General Beach site. In addition, Th. ciliatum had the highest phosphorous content in Aza'at site. On the other hand, the lowest values of phosphorus were recorded in Aza'at site for $H$. stipulacea, in NIOF site for $H$. uninervis \& H. ovalis and Th. ciliatum.

Generally sodium represents the dominant mineral in the four studied seagrasses where it ranges between 72.24 to $97.00 \mathrm{mgg}^{-1}$ dry wt. for $H$. stipulacea, 74.40 to $92.20 \mathrm{mgg}^{-1}$ dry wt for H. uninervis, 66.15 to $89.22 \mathrm{mgg}^{-1}$ dry wt for $H$. ovalis and 68.52 to $98.32 \mathrm{mgg}^{-1}$ dry wt and Th. ciliatum, respectively. It was clear that sodium content of the four seagrasses significantly increased in the summer season than in winter (Fig. 29 ). The highest value of sodium content of $H$. stipulacea and $H$. ovalis was recorded in NIOF site, while that of $H$. uninervis was in NIOF site and Abu Shaar site. In addition, Th. ciliatum had the highest sodium content in Abu Shaar sites. On the other hand, the lowest value of sodium content was recorded in Aza'at site for H. stipulacea, H. uninervis and Th. ciliatum and in General Beach site for H. ovalis.

Table 6 showed that potassium content of $H$. stipulacea and $H$. uninervis significantly increased in summer than in winter. In addition, the potassium content of the two species recorded its highest value in NIOF site with a significant value compared to the other three sites. On the other hand, the statistical analysis didn't record any significant difference in potassium content of $H$. ovalis and Th. ciliatum in the two seasons or in the four sites.

The statistical analysis indicated that there was a significant effect of seasonality and different locations on magnesium content of the studied four seagrasses. Table 6 showed that the highest magnesium content has been recorded in NIOF site in the two seasons for H. stipulacea, H. uninervis and Th. ciliatum but in General Beach for $H$. ovalis.

Statistically, there was a significant effect of seasonality and locations on magnesium content of the studied four seagrasses. Table 6 showed that the highest magnesium content has been recorded in NIOF site in the two seasons 
for $H$. stipulacea, H. uninervis and Th. ciliatum but in General Beach for $H$. ovalis.

Calcium content of $H$. stipulacea, H. uninervis and Th. ciliatum significantly increased in summer than in winter. Table 6 indicated that calcium content significantly increased in $H$. stipulacea and $H$. uninervis in NIOF compared to other sites in the two seasons. Where, Ca content of Th. ciliatum tissue increased in Abu Shaar in summer and in Aza'at in winter.

TABLE 6. Nutrients content $\left(\mathrm{N}, \mathrm{P}, \mathrm{Na}^{+1}, \mathrm{~K}^{+1}, \mathrm{Mg},{ }^{+2}\right.$ and $\mathrm{Ca}^{+2}$ ) of four seagrass species of four seagrasses species during summer (Sum) and winter (Win) seasons in 4 sites at Hurghada and Safaga, Red Sea Coast. (AS: Abu Shaar; MS: NIOF; GB: General Beach and Az: Aza'at site)

\begin{tabular}{|c|c|c|c|c|c|c|c|c|c|c|c|c|c|}
\hline \multirow{3}{*}{$\begin{array}{l}\frac{3}{\mathscr{e}} \\
\text { के }\end{array}$} & \multirow{3}{*}{ 站 } & \multicolumn{12}{|c|}{ Nutrient content ( $\mathrm{mg} \mathrm{g}^{-1}$ dry wt.) } \\
\hline & & \multicolumn{2}{|c|}{$\mathbf{N}$} & \multicolumn{2}{|c|}{$\mathbf{P}$} & \multicolumn{2}{|c|}{$\mathrm{Na}^{+1}$} & \multicolumn{2}{|c|}{$\mathbf{K}^{+1}$} & \multicolumn{2}{|c|}{$\mathrm{Mg}^{+2}$} & \multicolumn{2}{|c|}{$\mathrm{Ca}^{+2}$} \\
\hline & & Sum & Win & Sum & Win & Sum & Win & Sum & Win & Sum & Win & Sum & Win \\
\hline \multirow{4}{*}{ 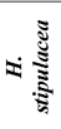 } & AS & 6.32 & 7.32 & 0.041 & 0.068 & 0.64 & 0.42 & 10.58 & 8.00 & 0.62 & 0.44 & 78.20 & 67.32 \\
\hline & MS & 9.24 & 10.76 & 0.046 & 0.086 & 1.06 & 0.80 & 12.92 & 10.54 & 0.92 & 0.52 & 97.00 & 82.00 \\
\hline & GB & 7.62 & 9.64 & 0.035 & 0.038 & 0.56 & 0.44 & 9.36 & 5.10 & 0.88 & 0.44 & 76.60 & 66.84 \\
\hline & $\mathbf{A z}$ & 8.84 & 9.96 & 0.021 & 0.028 & 0.44 & 0.52 & 6.64 & 4.92 & 0.62 & 0.42 & 74.46 & 72.24 \\
\hline \multicolumn{2}{|c|}{$\begin{array}{r}\text { LSD at 5\% for: } \\
\text { Sites }\end{array}$} & \multicolumn{2}{|c|}{ ns } & \multicolumn{2}{|c|}{0.014} & \multicolumn{2}{|c|}{0.19} & \multicolumn{2}{|c|}{2.10} & \multicolumn{2}{|c|}{0.23} & \multicolumn{2}{|c|}{8.45} \\
\hline & Seasons & & \multicolumn{2}{|c|}{0.022} & \multicolumn{2}{|c|}{0.20} & \multicolumn{2}{|c|}{2.24} & \multicolumn{2}{|c|}{0.35} & \multicolumn{2}{|c|}{9.25} \\
\hline \multirow{4}{*}{ ¿ } & AS & 11.34 & 12.16 & 0.032 & 0.038 & 1.20 & 1.26 & 6.46 & 5.10 & 0.56 & 0.46 & 91.40 & 90.20 \\
\hline & MS & 14.50 & 16.80 & 0.029 & 0.036 & 1.88 & 1.52 & 10.58 & 8.34 & 1.84 & 1.56 & 92.20 & 87.00 \\
\hline & GB & 8.16 & 7.30 & 0.057 & 0.076 & 1.76 & 1.30 & 4.90 & 4.04 & 1.72 & 1.36 & 75.84 & 74.40 \\
\hline & $\mathbf{A z}$ & 9.02 & 8.72 & 0.034 & 0.064 & 1.32 & 1.20 & 5.68 & 4.76 & 0.48 & 0.42 & 75.16 & 74.62 \\
\hline \multicolumn{2}{|c|}{$\begin{array}{r}\text { LSD at 5\% for: } \\
\text { Sites }\end{array}$} & \multicolumn{2}{|c|}{2.14} & \multicolumn{2}{|c|}{0.019} & \multicolumn{2}{|c|}{0.21} & \multicolumn{2}{|c|}{3.14} & & & & \\
\hline & Seasons & & & & & & & & & & 26 & & \\
\hline & AS & - & - & - & - & - & - & - & - & - & - & - & - \\
\hline$\stackrel{3}{*}$ & MS & 13.42 & 15.35 & 0.045 & 0.033 & 0.66 & 0.42 & 6.89 & 6.22 & 0.65 & 0.45 & 89.22 & 84.56 \\
\hline & GB & 13.42 & 15.35 & 0.065 & 0.042 & 0.54 & 0.40 & 6.01 & 5.11 & 1.08 & 0.63 & 71.25 & 66.15 \\
\hline & $\mathbf{A z}$ & - & & - & - & - & - & - & - & - & - & - & - \\
\hline LSD : & $\begin{array}{r}\text { 5\% for: } \\
\text { Sites }\end{array}$ & & & & & & & & & & 28 & & \\
\hline & Seasons & & & & 11 & & & & & & & & \\
\hline & $+\mathbf{A S}$ & 13.88 & 14.70 & - & - & 1.44 & 0.66 & 8.68 & 8.00 & 1.08 & 0.36 & 98.32 & 84.96 \\
\hline 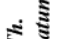 & MS & 10.52 & 10.20 & 7.210 & 6.30 & 1.00 & 0.64 & 8.16 & 6.30 & 1.32 & 0.44 & 93.10 & 72.42 \\
\hline$\Sigma$ & GB & & & - & - & - & - & - & - & & & & \\
\hline & $\mathbf{A z}$ & 11.36 & 12.01 & 0.073 & 0.052 & 1.22 & 1.24 & 7.21 & 6.30 & 0.85 & 0.22 & 74.80 & 68.85 \\
\hline LSD : & $\begin{array}{r}\text { t5\% for: } \\
\text { Sites }\end{array}$ & & 90 & & & & & & & & 12 & & \\
\hline & Seasons & & & 0. & & & & & & & 35 & & s \\
\hline
\end{tabular}

\section{Discussion}

Seagrass beds are an ecologically significant marine habitat providing food and shelter for bottom dwelling animals, which in turn provide food for fish, crustaceans and shore bird communities. Seagrass beds are covering about $0.1-$ $0.2 \%$ of the global ocean floor. Being a highly productive ecosystem they fulfill a key role in the coastal zone. Important ecological and economic functions of seagrass beds have been widely acknowledged, notably their importance to 
fisheries (Jackson et al., 2002) and their role in preventing coastal erosion and siltation of coral reefs (Duarte, 2002). Despite its value and importance they are very sensitive and its health is affected by a wide range of natural and human disturbances that occur at a range of spatial and temporal scales.

Despite the importance of the seagrass meadows, a relatively little information is available about its distribution on the Egyptian Red Sea coast. The number of species of seagrass recorded from the shallow areas of the Red Sea coast during the last decades are never exceed 11 species (Wahbeh, 1981 and Aleem, 1984) where, in the recent publications only 6 or 7 species are commonly seen specially in the northern part of the Red Sea (Geneid, 1995).

Five seagrasses species were recorded in the studied area similar to the findings of Geneid (1995), Geneid (2009) and Mohamed (2010), they found a significant increase in their abundance towards the northern Red Sea. The data indicated also that $H$. stipulacea seagrass represented the dominant species in the studied sites according to their presence (100\%) in the four sites, density and biomass. Recently, $H$. uninervis was recorded in NIOF site with high abundance while it wasn't recorded in the study of Geneid (1995). In addition, Syringodium isoetifolium was recorded for the first time in General Beach site at Safaga. This indicated that changes have been occurred in these environments to become suitable for appearance of these species.

NIOF site showed high variation in habitats according to sediment characteristics and water depth. This variation affected on species diversity, however, Th. ciliatum species growing with high density and biomass in conglomerate sediments constructed from coarse sand. In addition their density and biomass didn't affected by water depth. While, H. stipulacea were found to be associated with Th. ciliatum in the NIOF, Abu Shaar and Aza'at sites. Noticeably, $H$. stipulacea have the ability to grow in different habitats (Conglomerate, coarse sand and fine sand sediments). So it represented the dominant species in the studied sites.

$H$. uninervis seagrass also represented a common species in the studied sites. Biomass and density of $H$. uninervis are highly affected by environmental conditions. Biomass and density recorded their highest values when the seagrass grow in pour stands (as in stands $5 \& 6$ in NIOF site) and recorded their lowest values when growing associated to Th. ciliatum and $H$. stipulacea (as in Abu Shaar and Aza'at sites). On the other hand, its association to $H$. stipulacea and $H$. ovalis showed low effect on its biomass and density compared to the effect of Th. ciliatum. These results indicated that Th. ciliatum is a strong competitor in its habitat

The present results indicated that there was a positive correlation between sediment texture and species distribution. However, Th. ciliatum prefers conglomerate sediment. While, $H$. uninervis and $H$. ovalis seagrasses prefer

Egypt. J. Bot., 56, No. 1 (2016) 
growing in sandy sediment. The relation between type of sediment texture and the species of seagrass inhabiting this sediment come in agreement with the findings of De Falco et al. (2006) and Mohamed (2010).

The new records of $H$. uninervis in NIOF site and Syringodium isoetifolium in General Beach, suggested that these areas have been exposed to certain changes in the last decade causing disturbance in seagrass distribution. These changes most probably generated from the land filling activities preformed in Hurghada and Safaga during the last decade (GEF/WB, 1998). The effect of the anthropogenic activities on the distribution and structure of seagrass community is also supported by the findings of Terrados et al. (1999) and Cavazza et al. (2000).

The present study records high sediment organic matter content in the seagrasses beds. Many studies confirm these findings as Mohamed (2010) who found that organic matter content within seagrass beds significantly higher than in the adjacent sand habitat. This indicated also that there was a positive correlation between organic matter and fine particles of sediment. However, stands $5 \& 6$ in NIOF and stands of General Beach sites mainly were constructed from fine sand and also contain the highest values of organic matter.

The floristic parameters in the present study indicated that the seagrasses grow throughout the year in the studied sites. The seasonal monitoring on seagrass beds showed that the values of shoot density and biomass increased through the summer season than winter. On the other hand, shoot biomass and density varied for each seagrass in the four studied sites, this may be due to the difference in water depth and sediment type. Where, the present data indicates that Th. ciliatum recorded its highest biomass and density in Abu Shaar and Aza'at sites, the two sites characterized by high depth and conglomerate sediments. It is also clear that $H$. uninervis and $H$. stipulacea recorded their highest biomass and density in fine sand sediments (stand 5\&6 in NIOF and General Beach sites) and recorded their lowest biomass and density in coarse sand sediments (Abu Shaar and Aza'at sites). Noticeably, H. ovalis seagrass are growing only in fine sand sediments and under low depth. Similar results have been obtained by Aleem (1984), Price and Colas (1992) and Mohamed (2010).

Seagrass productivities usually exhibit distinct seasonal variations, with rates increasing during spring and summer and decreasing during fall and winter. As temperature significantly affects the biochemical processes involved in photosynthesis and respiration, it is considered a major factor controlling seasonal seagrass growth (Lee et al., 2007).

Water temperature and irradiance often correlate and exhibit similar seasonal trends, and thus, it can be difficult to separate these two environmental parameters with regard to seagrass growth and production (Kaldy, 2006). 
Photosynthetic parameters often show seasonal variability (Alcoverro et al., 1998). The direct effects of increased temperature will depend on the individual species, thermal tolerances and their optimum temperatures for photosynthesis, respiration and growth (Kaldy, 2006).

In the present work, the content of the Photosynthetic pigments (chl $a$ and chl $b$ ) increased in $H$. stipulacea and $H$. uninervis leaves during winter than summer and these results match with the theory, low-light acclimation could be affected in seagrasses, by maintenance of a large population of inactivated PSII reaction centers. The advantage would be that these inactivated centers could function as effective energy quenchers of trapped light energy in fluctuating light climates. This would lower effective quantum yield, yet prevent photoinhibitory damage and increasing chlorophyll content (Ralph, 1999). On the other hand, the photosynthetic pigments content of Th. ciliatum and H. ovalis leaves was higher in summer than in winter, this may be due to increasing water temperature which will directly affect seagrass metabolism and the maintenance of a positive carbon balance (Zimmerman et al., 1989). Terrados and Ros (1995) recorded that Cymodocea nodosa increase their photosynthesis and respiration over a wide range of temperatures. Seasonal variations in temperature may also impose species-specific threshold effects (Marsh et al., 1986).

Chlorophyll $a$ and $b$ content of $H$. stipulacea and $H$. uninervis seagrasses recorded their highest content in NIOF site, this result indicated that these two species adapted to low depth. Drew (1979) showed that H. stipulacea collected from a depth at $2 \mathrm{~m}$ exhibited higher rates of photosynthesis than plants collected from $18 \mathrm{~m}$. The higher chlorophyll content in $H$. ovalis leaves were recorded in General Beach than NIOF site, the habitat where H. ovalis collected is shallower in General Beach than NIOF, in addition, H. ovalis was shaded by dense growth of $H$. stipulacea in NIOF. These conditions lead to reduction in irradiance, where photoadaptive responses in seagrasses to reduction in irradiance have been reflected in seagrasses through decreases in plant size, biomass and chlorophyll composition including chl a:b ratios and chl content (Peralta et al., 2002).

The highest chlorophyll contents of Th. ciliatum were recorded in the deepest sites (Abu Shaar and Aza'at). This result supports the findings of Ruiz and Romero (2003).

The variation in photosynthetic pigments has its parallel effect on the metabolic products. Therefore, the present results showed a positive correlation between photosynthetic pigments content and total carbohydrates and protein contents. The amounts of total carbohydrates and protein show the same responses to photosynthetic pigments to seasonal variation and water depth. The compositions of organic solutes in seagrasses have strong seasonal tendencies (Touchette and Burkholder, 2002). 
It is known that increase or reduction of soluble organic solutes (soluble sugars, free amino acids and proline) in most plants represents a response to the environmental factors; high or low temperature, high or low light intensity, salinity and others Longstaff and Dennison (1999).

The present study indicates that the soluble organic solutes as soluble sugars, free amino acids and proline significantly increased in the four seagrasses growing in the four sites in summer season. Summer season (in August) in these areas is characterized by temperature that ranges from 26.2 to $33.9{ }^{\circ} \mathrm{C}$. The studied sites are shallow coastal habitats and affected directly by seasonal changes especially in temperature and light. Increasing temperature in summer represents a stress on the four seagrasses so the plants adapted to this increase by accumulating the soluble organic solutes. Plants growing in low depths as in some stands of NIOF and stands of General Beach sites are highly affected by the increase in summer temperature. The present study recorded increase in soluble sugar, free amino acids and proline contents in $H$. stipulacea, $H$. uninervis and Th. ciliatum growing in NIOF site than in the other three sites. On the other hand, the soluble organic solutes increased in $H$. ovalis seagrass in the General Beach site which is shallower than the stands $7 \& 8$ in the NIOF site. This result was in agreement with the results obtained for Halophila pinifolia by Longstaff and Dennison (1999), they reported that physiological responses to light reductions include changes in amino acids content. In addition, Conacher et al. (1994) concluded that the effect of temperature may be complicated by interactions with salinity so proline appears to be the principle organic osmotica (Ye and Zhao, 2003). Touchette and Burkholder (2007) found that high temperatures and salinity promoted significant increases in sucrose levels.

Availability of nutrients such as nitrogen and phosphorus may limit seagrass productivity, particularly in oligotrophic environments. Seagrasses are able to utilize nutrients from both the water-column and sediment porewater. Nutrient concentrations within seagrass tissue and nutrient availability in porewater have been used independently to assess nutrient status for seagrass meadows (McGlathery et al., 2001).

The present data of water analysis show no significant difference between nutrients concentration of the four seagrasses in the four sites. This result indicated that habitats had no effect on seagrasses mineral content. So it can be considered that climatic conditions (light and temperature) have the main influence on the nutrients content in seagrasses tissues.

Nitrogen and phosphorus content of the four seagrasses increased in winter than in summer at the four studied sites; this may be due to low light in winter. This result matches with the findings of Ruiz and Romero (2001), who showed accumulation of nitrogenous compounds during low light exposure. 
The increase in sodium, potassium, calcium and magnesium contents in seagresses tissues in summer than in winter indicated that the raise in environmental temperature in summer caused stress on seagrasses, this effect increased with low water depth. Increase in temperature resulted in increase in evaporation and increase in water salinity. So the plants accumulate quantities of minerals as inorganic osmoprotectants. This mechanism is known in plants subjected to stresses (salinity, drought, heat, cold, etc)

The mineral contents $(\mathrm{Na}, \mathrm{K}, \mathrm{Ca}$ and $\mathrm{Mg}$ ) of the studied seagrasses are lower than those of mangrove plant Avicennia marina (Khalafallah, 2003). This indicated that seagrasses posses techniques for salt avoidance.

The difference in nutrients content of the seagrasses in the four sites may be due to sediment type, sediment organic matter and water depth. Kilminster et al. (2006) found that, increased organic matter concentration increased seagrass nutrients.

In conclusion, the recent study indicated that the four studied seagrass distribution is affected by sediments types. In addition, the climatic factors and water are the main environmental factors affecting on seagrasses productivity and metabolic processes.

Improvement seagrass researches in Egypt; further researches are required on seagrass investigation, biology of more seagrass species, ecosystem function of seagrass meadows and the environmental factors influencing distribution and abundance. In addition, seagrass protection sites should be done in future.

\section{References}

Alcoverro, T., Manzanera, M. and Romero, J. (1998) Seasonal and age-dependent variability of Posidonia oceanica (L.) Delile photosynthetic parameters. J Exp Mar Biol Ecol., 230: 1-13.

Aleem, A.A. (1984) Distribution and ecology of seagrass communities in the western Indian Ocean. Deep-sea Res., 31: 919-933

Allen, S.E. (1989) "Chemical Analysis of Ecological Materials". $2^{\text {nd }}$ ed. Black Well Sci. Pub. Osney. Nd Oxford, London.

American Public Health Association, (1995) "Standard Methods for the Examination of Water and Wastewater", $19^{\text {th }}$ ed. Washington, DC, USA.

Association of Official Agricultural Chemists (A.O.A.C.), (1975.) "Official methods of analysis", $12^{\text {th }}$ ed. Washington, D. C., U.S.A.

Barbier, E.B., Hacker, S.D., Kennedy, C., Koch, E.W., Stier, A.C. and Silliman, B.R. (2011) The value of estuarine and coastal ecosystem services. Ecol. Monogr., 81:169193

Egypt. J. Bot., 56, No. 1 (2016) 
Bates, L.S., Waldren, R.P. and Teare, T.D. (1973) Rapid determination of free proline for water stress studies. Plant and Soil, 39: 205.

Bjork, M., Short, F.T., McLeod, E., Beer, S. (2008) "Managing Seagrasses for Resilience to Climate Change". IUCN, Gland, Switzerland.

Bologna, A.X. and Suleski, A.J. (2013) Assessment of seagrass floral community structure from two Caribbean marine protected areas. Gulf and Caribbean Research, 25: $19-27$.

Bradford, M.M. (1976) A rapid and sensitive method for the quantitation of microgram quantities of protein utilizing the principle of protein- dye binding. Analyt. Biochem., 72: $248-254$.

Boulos, L. (2005) "Flora of Egypt, Volume 4: Monocotyledons (Alismataceae-Orchidaceae). Al Hadara Publishing, Cairo, Egypt

Bulleri, F., and Chapman. M.G. (2010) The introduction of coastal infrastructure as a driver of change in marine environments. J Appl Ecol., 47: 26-35.

Carver, R.E. (1971) "Procedure in Sedimentary Petrology". John Willey and Sons, Inc., Canada, pp. 653.

Cavazza, W., Immordino, F., Moretti, L., Peirano, A., Pironi, A., and Ruggiero, F. (2000) Sedimentological parameters and seagrass distributions as indicators of anthropogenic coastal degradation at Monterosso Bay (Ligurian Sea, NW Italy). $J$ Coast Resear, 16: 295-305.

Chaplin, M.F. and Kennedy, J.F. (1994) "Carbohydrate analysis". $2^{\text {nd }}$ ed: A practical approach Oxford University Press, Oxford. New York, Tokyo. pp: 324.

Conacher, C.A., Poiner, I.R. and O'Donohue, M. (1994) Morphology, flowering and seed production of Zostera capricorni Aschers, in sub tropical Australia. Aquat. Bot., 49: 33-46.

De Falco, D., Baroli, M., Murru, E., Piergallini, G., and Cancemi, G. (2006) Sediment analysis evidences two different depositional phenomena influencing seagrass distribution in the Gulf of Oristano (Sardinia, western Mediterranean). J. Coasl Resear, 22 (5): 1043-1050.

den Hartog, C. (1970) "The Seagrasses of the World". North-Holland Publ. Co., Amsterdam, pp. 275.

Drew, E.A. (1979) Physiological aspects of primary production in seagrasses. Aquat Bot., 7: $139-150$.

Duarte, C.M. (2002) The future of seagrass meadows. Environ. Conserv., 29 : 192-206.

Dubois, M., Smith, F., Gilles, K.A., Hamilton, J.K. and Reber, P.A. (1956) Colorimetric method for determination of sugar and related substances. Anal. Chem., 28: 350 . 
Duke, N.C., Meynecke, J.O., Dittmann, S., Ellison, A.M., Anger, K., Berger, U., Cannicci, S., Diele, K., Ewel,K.Cm., Field, C.D., Koedam, N., Lee, S. Y., Marchand, C., Nordhaus, I. and Dahdouh-Guebas, F. (2007) A world without mangroves. Science, 317: 41

El Shaffai, A. (2011) "Field Guide to Seagrasses of the Red Sea". Rouphael, A. and A. Abdulla, Eds. $1^{\text {st }}$ ed Gland, Switzerland: IUCN and Courbevoie, France.

English, S., Wilkinson, C. and Basker, V. (1997) "Survey manual for tropical marine resources" ( $\left.2^{\text {nd }} \mathrm{ed}\right)$. Australian Institute of Mar. Sci.. Townsville, pp.119-195.

Geneid, Y.A. (2009) Distribution of seagrass species along the Egyptian Red Sea coast. Egyptian Journal of Aquatic Research, 35 (1): 58-68

Geneid, Y.A. (1995) Ecological study on the seagrass at some Egyptian Red Sea Coat. MSc Thesis, Oceanography Depart. Faculty of Science, Swez Canal University.

Green, E.P., and Short, F.T. (2003) "World Atlas of Seagrasses". Published in association with UNEP-WCMC by the University of California Press, California. Berkeley, USA.298 pp.

Heck, K.L., Carruthers, T.J., Duarte, C.M., Hughes, A.R., Kendrick, G.A., Orth, R.J. and Williams, S.L. (2008) Trophic transfers from seagrass meadows subsidize diverse marine and terrestrial consumers. Ecosystems, 11: 1198-1210.

Heck, K.L., Hays, C. and Orth, R.J. (2003) A critical evaluation of the nursery role hypothesis for seagrass meadows. Mar Ecol Prog Ser, 253: 123-136.

Jackson, E.L., Rowden, A.A., Attrill, M.J., Bossy, S.F. and Jones, M.B. (2002) Comparison of fish and mobile macro-invertebrates associated with seagrass and adjacent sand at St. Catherine Bay Jersey (English Channel): Emphasis on commercial species. Bull Mar Sci., 71: 1341-1333.

Jackson, M.L. (1967) "Soil chemical Analysis". Hall of India Private, New Delhi, India. Prentice. Hall, Inc. N. J., 248 pp.

Kaldy, J.E. (2006) Production ecology of the non-indigenous seagrass, dwarf eelgrass (Zostera japonica Ascher, \& Graeb.), in a Pacific Northwest Estuary, USA. Hydrobiol., 553: 201-217.

Khalafallah, A.A. (2003) Ecological adaptation of Avicennia marina plants growing at Qussier, Red Sea Coast, Egypt. Ph. D. Botany Depart. Fac. of women's for Arts, Science and Education, Ain Shams Univ.

Kilminster, K.L., Walker, D.I., Thompson, P.A. and Raven, J.A. (2006) Limited nutritional benefit to the seagrass Halophila ovalis, in culture, following sediment organic matter enrichment. Estuar. Coast. Shelf Sci. 68: 675-685.

Kim, J.B., Lee, W, Lee, K., and Park, J. (2013) Growth Dynamics of Eelgrass, Zostera marina, in the Intertidal Zone of Seomjin Estuary, Korea. Ocean Sci. J. 48 (3): 239250.

Egypt. J. Bot., 56, No. 1 (2016) 
Kruscal, J.B. (1964) Nonmetric multidimensional scaling: A numerical method. Psychometrika, 29: 115-129.

Lawrence, A.J. and Soame, J.M. (2004) The effects of climate change on the reproduction of coastal invertebrates. Environ. Conserv., $146: 29-39$.

Lee, K.S., Park, S.R. and Kim. Y.K. (2007) Effects of irradiance, temperature, and nutrients on growth dynamics of seagrasses: A review. Exp Marine Biol and Ecol., 350: $144-175$.

Longstaff, B.J. and Dennison, W.C. (1999) Seagrass survival during pulsed turbidity events: the effects of light deprivation on the seagrass Halodule pinfolia and Halophila ovalis. Aquat. Bot., 65 (1-4): 105-121.

Marques, J.C., Nielsen, S.N., Pardal, M.A. and Jrgensen, S.E. (2003) Impact of eutrophication and river management within a framework of ecosystem theories. Ecological Modelling 166: 147-168.

Marsh, J.A.J., Dennison, W.C. and Alberte, R.S. (1986) Effects of temperature on photosynthesis and respiration in eelgrass (Zostera marina L.). J Exp. Mar. Biol. Ecol., 101: 257-267.

McGlathery, K.J., Berg, P. and Marino, R. (2001) Using porewater profiles to assess nutrient availability in seagrass-vegetated carbonate sediments. Biogeochemistry (Dordrecht), 56: 239-263.

Mohamed, E.O. (2010) Ecological Studies on Fauna Associated with Seagrass Habitat at Hurghada-Red Sea. M.Sc. Zoology Department, Faculty of Science, Al Azhar University.

Moore, S. and Stein, W.H. (1954) A modified ninhydrin reagent for the photometric determination of amino acids and related compounds. J. Biol. Chem., 211: 907.

Peralta, G., Pérez-LLoréns, J.L., Hernández, I. and Vergara, J.J. (2002) Effects of light availability on growth, architecture and nutrient content of the seagrass Zostera noltii Hornem. J. Exp. Mar. Biol. Ecol., 269 : 9-26.

Persga (2004) Standard Survey Methods for Key Habitats and Key Species in the Red Sea and Gulf of Aden. PERSGA Technical Series No. 10.

Price, A.R.G. and Colas, S.L. (1992) Aspects of seagrass ecology along the western Arabian Gulf coast. Hydrobiol, 234 : 129-141.

Ralph, P.J. (1999) Light-induced photoinhibitory stress responses of laboratory-cultured Halophila ovalis. Bot, Ma., $42: 11-22$.

Ruiz, J.M. and Romero, J. (2003) Effects of disturbances caused by coastal constructions on spatial structure, growth dynamics and photosynthesis of the seagrass Posidonia oceanica. Mar Pollut Bull., 46 : 1523-1533. 
Ruiz, J.M. and Romero, J. (2001) Effects of in situ experimental shading on the Mediterranean seagrass Posidonia oceanica.Mar. Ecol. Progr. Ser., 215 : 107_120.

Short, F.T., McKenzie, L.J., Coles, R.G., Vidler, K.P., Gaeckle, J.L (2006) "Seagrass Net Manual for Scientific Monitoring of Seagrass Habitat", Worldwide edition. University of New Hampshire Publication. 75 pp.

Snedecor, G.M. and Cochran, W.C. (1969) "Statistical Methods". $6^{\text {th }}$ ed. Iowa Univ. press. Ames. Iowa U.S.A.

Terrados, J. and Ros, J.D. (1995) Temperature effects on photosynthesis and depth distribution of the seagrass Cymodocea nodosa (Ucria) Ascherson in a Mediterranean coastal lagoon: The Mar Menor (SE Spain). Mar. Ecol., 16 : 133-144.

Terrados, J., Duarte, C.M., Kamp-Nielsen, L., Agawin, N.S.R., Gacia, E., Lacap, D., Fortes, M.D., Borum, J., Lubanski, M., and Greve, T. (1999) Are seagrass growth and survival constrained by the reducing conditions of the sediment? Aquat Bot, 65: 175-197.

Touchette, B.W. and Burkholder, J.M. (2002) Seasonal variations in carbon and nitrogen constituents in eelgrass (Zostera marina L.) as influenced by increased temperature and water-column nitrate. Bot. Mar., $45: 23-34$.

Touchette, B.W. and Burkholder, J.M. (2007) Effects of temperature and nitrate on phosphomonoesterase activities between carbon source and sink tissues in Zostera marina L. J. Exper. Mar. Biol. and Eco., 342 : 313-324.

VonWettstein, D. (1954) Chlorophyll lethal factoren und der submikroskopische formwechsel der plastiden. Exp. Cell Res., 12: 427-433.

Wahbeh, M.I. (1981) Distribution, Biomass, Biometry and some associated fauna of the seagrass community in the Jordan Gulf of Aqaba., Proc. 4th. Int. Coral Reef Symp. Manila, Vol. 2 : 453-459.

Waycott, M., Duarte, C.M., Carruthers, T.J.B., Orth, R.J., Dennison, W.C., Olyarnik, S., Calladine, A., Fourqurean, J.W., HeckJr., K.L., Hughes, A.R., Kendrick, G.A., Ken- worthy, W.J., Short, F.T. and Williams, S.L. (2009) Accelerating loss of seagrasses across the globe threatens coastal ecosystems. Proc. Nat. Acad. Sci., U.S.A. 106 : 12377- 12381.

Ye, C.J. and Zhao, K.F. (2003) Osmotically active compounds and their localization in the marine halophyte eelgrass. Bio. Plan, $46: 137-140$.

Zimmerman, R.C., Smith, R.D. and Alberte, R.S. (1989) Thermal acclimation and whole-plant carbon balance in Zostera marina L. (eelgrass). J. Environ. Mar. Biol., Ecol., 130: 93-109. 


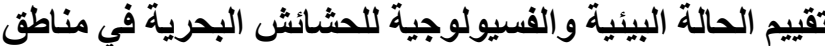 ممثلة بقطاعي الغردقة وسفاجا، ساحل البحر الأحمر، مصر في من}

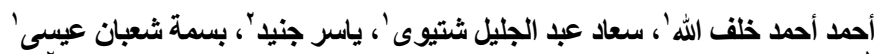

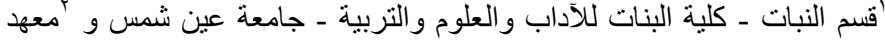

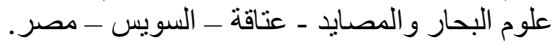

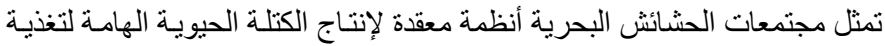

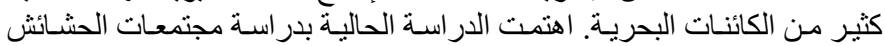

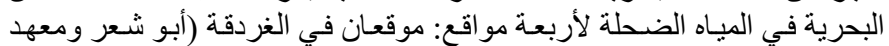

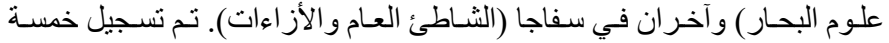

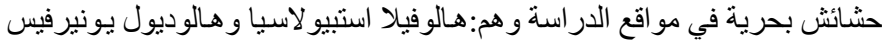

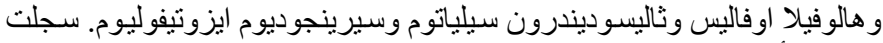

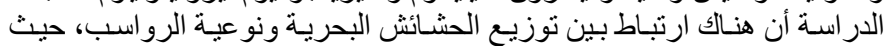

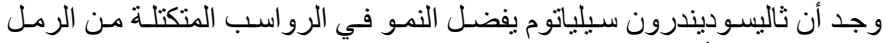

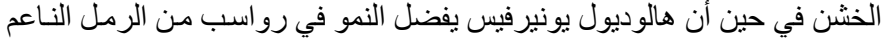

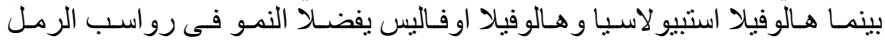

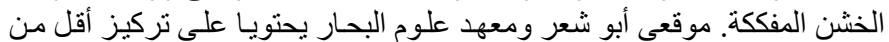

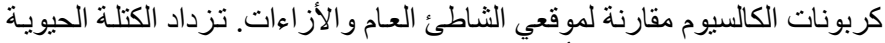

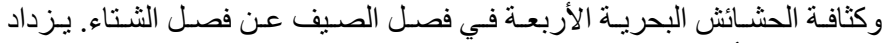

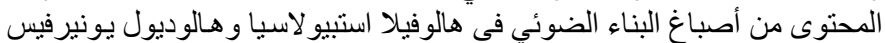

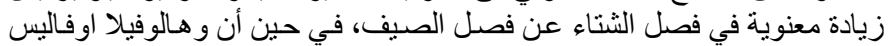

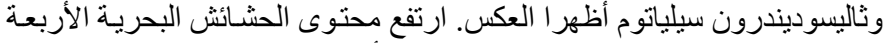

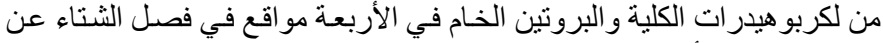

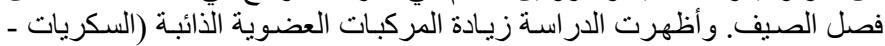

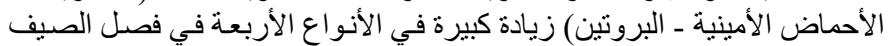

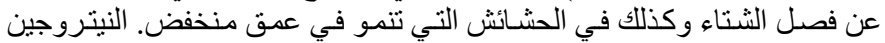

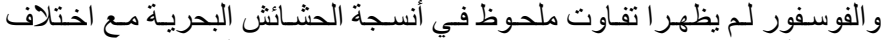

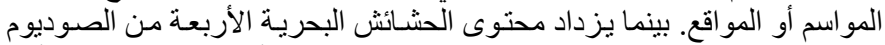

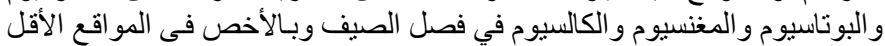

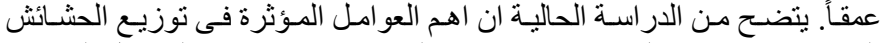

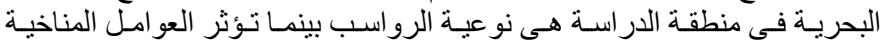

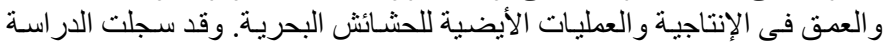

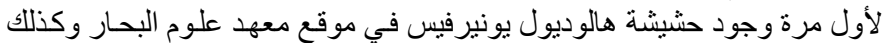

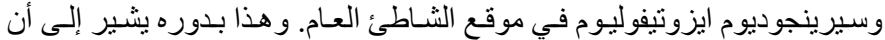

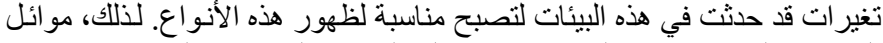

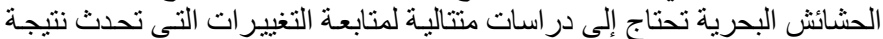
للتأثثير ات الطبيعية والبشرية. تصنية 